\title{
Small-scale on-site treatment of fecal matter: comparison of treatments for resource recovery and sanitization
}

\author{
Mariya E. Kelova ${ }^{1} \cdot$ Aasim M. Ali ${ }^{2,3} \cdot$ Susanne Eich-Greatorex ${ }^{1} \cdot$ Peter Dörsch $^{1} \cdot$ Roland Kallenborn $^{2} \cdot$ Petter D. Jenssen ${ }^{1}$
}

Received: 25 August 2020 / Accepted: 8 February 2021 / Published online: 5 March 2021

(C) The Author(s) 2021, corrected publication 2021

\begin{abstract}
On-site small-scale sanitation is common in rural areas and areas without infrastructure, but the treatment of the collected fecal matter can be inefficient and is seldom directed to resource recovery. The aim of this study was to compare low-technology solutions such as composting and lactic acid fermentation (LAF) followed by vermicomposting in terms of treatment efficiency, potential human and environmental risks, and stabilization of the material for reuse in agriculture. A specific and novel focus of the study was the fate of native pharmaceutical compounds in the fecal matter. Composting, with and without the addition of biochar, was monitored by temperature and $\mathrm{CO}_{2}$ production and compared with LAF. All treatments were run at three different ambient temperatures $(7,20$, and $38^{\circ} \mathrm{C}$ ) and followed by vermicomposting at room temperature. Materials resulting from composting and LAF were analyzed for fecal indicators, physicochemical characteristics, and residues of ten commonly used pharmaceuticals and compared to the initial substrate. Vermicomposting was used as secondary treatment and assessed by enumeration of Escherichia coli, worm density, and physicochemical characteristics. Composting at $38^{\circ} \mathrm{C}$ induced the highest microbial activity and resulted in better stability of the treated material, higher $\mathrm{N}$ content, lower numbers of fecal indicators, and less pharmaceutical compounds as compared to LAF. Even though analysis of $\mathrm{pH}$ after LAF suggested incomplete fermentation, E. coli cell numbers were significantly lower in all LAF treatments compared to composting at $7^{\circ} \mathrm{C}$, and some of the anionic pharmaceutical compounds were detected in lower concentrations. The addition of approximately 5 vol \% biochar to the composting did not yield significant differences in measured parameters. Vermicomposting further stabilized the material, and the treatments previously composted at $7^{\circ} \mathrm{C}$ and $20^{\circ} \mathrm{C}$ had the highest worm density. These results suggest that in small-scale decentralized sanitary facilities, the ambient temperatures can significantly influence the treatment and the options for safe reuse of the material.
\end{abstract}

Keywords Feces $\cdot$ Dry toilet $\cdot$ On-site sanitation $\cdot$ Composting toilet $\cdot$ Resource recovery $\cdot$ Pharmaceuticals $\cdot$ Human excreta

The original online version of this article was revised: The images of figures 6,8 and 10 are correctly presented in this paper.

Responsible editor: Philippe Garrigues

Mariya E. Kelova

mariya.kelova@nmbu.no

Aasim M. Ali

Aasim.Ali@hi.no

Susanne Eich-Greatorex

susanne.eich@nmbu.no

Peter Dörsch

peter.doersch@nmbu.no

Roland Kallenborn

roland.kallenborn@nmbu.no
Petter D. Jenssen

petter.jenssen@nmbu.no

1 Faculty of Environmental Sciences and Natural Resource Management (MINA), Norwegian University of Life Sciences (NMBU), Fougnerbakken 3, NO-1433 Ås, Norway

2 Faculty of Chemistry, Biotechnology and Food Science (KBM), Norwegian University of Life Sciences (NMBU), Chr. M. Falsens vei 1, NO-1433 Ås, Norway

3 Department of Contaminants and Biohazards, Institute of Marine Research, NO-5817 Bergen, Norway 


\section{Introduction}

Only $38 \%$ of the global population have access to an improved sanitation facility connected to centralized treatment (WHO and UNICEF 2017). Hence, the majority of the remaining $72 \%$ uses on-site sanitation systems. Such systems are common in areas without or only with minor municipal infrastructure and in rural, remote, and small settlements and are commonly dry sanitation systems (WHO and UNICEF 2017). They have low resource input - no water and no complex and expensive infrastructure and, depending on the system, use little to no electricity (Tilley et al. 2014). The fecal sludge in those systems consists of mostly urine and feces and therefore is concentrated in a small, undiluted volume with high concentration of macro- and micronutrients, as well as organic matter, which can be valuable inputs to the surrounding agroecosystems. However, the fecal sludge is also associated with hazards as pathogens and micropollutants, including pharmaceuticals and other chemicals of emerging concern (Schönning et al. 2007; Hester and Harrison 2016; de Oliveira et al. 2020; Gros et al. 2020).

Most on-site sanitation systems do not treat the fecal sludge to facilitate safe reuse (WHO and UNICEF 2017). Currently, the common practices are not considering treatment or resource recovery and rely on subsequent storage or disposal (Strande and Brdjanovic 2014; Tilley et al. 2014). Dry composting toilets are considered one of the best current options for on-site treatment in terms of resource recovery (Orner and Mihelcic 2018; McConville et al. 2020). However, composting is not always successful, and the resulting material is usually neither stabilized nor sanitized (Niwagaba et al. 2009; Hill et al. 2013). Few studies have addressed this important aspect by examining how to improve the treatment physically or chemically by, i.e., solar heating (Redlinger et al. 2001), different bulking materials (McKinley et al. 2012; Hashemi et al. 2019), and/or amendments such as biochar (Hijikata et al. 2015) or urea (Vinnerås 2007). Others have focused on modifying the treatment by vermicomposting (Yadav et al. 2011), lactic acid fermentation (LAF) (Andreev et al. 2018), or fly larvae composting (Lalander et al. 2013a).

Combinations of treatments are considered promising. Integrated composting-vermicomposting has been investigated for a variety of organic wastes (Lim et al. 2016) including fecal slurry (Yadav et al. 2012). The material is first sanitized by thermophilic composting and conditioned further with earthworms to improve the quality of the end product. Precomposting facilitates better conditioning because earthworms are vulnerable to thermophilic temperatures and toxic compounds in the organic wastes (Yadav et al. 2012). Another treatment combination for on-site sanitation is pre-treatment with LAF followed by thermophilic composting (Andreev et al. 2016) or vermicomposting (De Gisi et al. 2014). LAF is easy to manage and reduces quickly fecal pathogens, while the organic matter and nutrients are retained (Odey et al. 2018a). However, LAF alone does not sufficiently stabilize and sanitize fecal matter, and further treatment is needed before application as soil conditioner or fertilizer (Andreev et al. 2018). The combination of LAF and vermicomposting is part of the Terra Preta sanitation, which is inspired by ancient practices of organic waste management for soil fertility in the Amazon region (De Gisi et al. 2014). Central to the Terra Preta sanitation concept is the addition of carbonaceous pyrogenic material as biochar to retain nutrients and increase the product value for improving soil health and fertility. Biochar amendment in organic waste treatment has been shown to have benefits for agricultural application, with respect to retention of nutrients and pollution remediation $(\mathrm{Wu}$ et al. 2017). However, the efficiency for pollutant removal has not yet been assessed.

Biological transformations of fecal matter in on-site sanitation systems based on composting, vermicomposting, and LAF, even though considered as low-tech, can contribute to a cleaner local environment. If those practices are suitable in the local social and economic context, they have the potential to increase sustainability through recirculating nutrients and organic matter from excreta to agriculture and contribute to the currently propagated circular bioeconomy strategy. It is therefore important to explore different treatments in more detail and compare them directly with regard to the risks to human health and content of contaminants such as pharmaceutical residues and others, as well as assess their value for agricultural application.

Both composting and fermentation rely on biological processes, which are influenced by environmental conditions and management practices. Microbial transformations of the organic material are the foundation of these processes and are strongly influenced by, e.g., ambient temperatures. In smallscale systems, such as decentralized on-site sanitary facilities, the influence of temperature will be important. The fecal matter treatment in cold environments may be inhibited requiring different design considerations and management (Chen et al. 2020).

The aim of this study was to compare small-scale conventional composting with and without addition of biochar and to compare it to lactic acid fermentation (LAF) at three different ambient temperatures $\left(7,20\right.$, and $\left.38^{\circ} \mathrm{C}\right)$. We further evaluated the use of vermicomposting at room temperature as a secondary treatment step. The composting process was investigated by measuring microbial activity and was compared to LAF by determining the changes in physicochemical characteristics and enumerating fecal indicators as well as quantifying selected pharmaceutical residues. After vermicomposting, the different treatments were evaluated with respect to changes in physicochemical characteristics, abundance of fecal indicators, and worm density. 


\section{Materials and methods}

In order to compare small-scale on-site sanitization strategies for fecal matter, a controlled laboratory experiment was carried out with three fecal matter mixtures, each run in three replicates at three different temperatures. All treatments were subjected to degradation (by composting or LAF) under controlled temperature for 71 days, followed by 15 days of composting and 77 days of vermicomposting at room temperature.

\section{Composting reactors and experimental setup}

The experiment was conducted in tailor-made 16-L smallscale reactors. The reactor size was chosen, as a compromise between real-world size for on-site sanitation from a single toilet and the need for multiple replicates under controlled conditions. As suitable for the purpose, commercially available bokashi bins $(0.38 \times 0.33 \times 0.27 \mathrm{~m})$ were used. The bins used for LAF were kept closed, whereas the reactors used for composting were modified by replacing the tap at the bottom with a tube connector. The connector was linked via $6-\mathrm{mm}$ (inside diameter) tube to a liquid trap and a pump (Mini Diaphragm Vacuum Pump LABOPORT, model N86 KN.18, KNF, Freiburg, Germany) to pump air through the material (Fig. 1a). Further, two holes were drilled on the two top opposite short sides and connected with hoses (inside diameter $3 \mathrm{~mm}$ ) to a gas analyzer (Fig. 1b). When the lid was closed, this created a closed circuit for the headspace air and allowed to determine rates of $\mathrm{CO}_{2}$ production. Aeration and $\mathrm{CO}_{2}$ measurements were operated sequentially.

Replicate reactors were placed in three climate-controlled rooms, maintaining ambient temperatures of 7,20 , and $38^{\circ} \mathrm{C}$, respectively, for 71 days. The temperatures were chosen to demonstrate a range of low, normal, and high ambient temperatures. The $7^{\circ} \mathrm{C}$ is representative of cold environments and $20^{\circ} \mathrm{C}$ of warm environments, and $38^{\circ} \mathrm{C}$ corresponds to additional heating, which increases the microbial activity and speeds up the composting (Sundberg et al. 2004; Eklind et al. 2007). At each temperature, there were three replicates of (1) composting mix from excreta with sanitary bark (Mix C); (2) composting mix with excreta, sanitary bark, and biochar (Mix CB); and (3) fermenting mix of excreta, sanitary bark, and biochar (Mix F) (Fig. 2). The compost reactors were dynamically incubated by sucking ambient air top-down through the substrate (negative aeration). For this, a vacuum pump was connected to the bottom of each of the six composting reactors (Fig. 1a) via equally long tubing to avoid pressure differences between the reactors. The pump was operated for $15 \mathrm{~min}$ followed by $30 \mathrm{~min}$ off. This aeration regime was chosen to avoid drying out of the substrate. The aeration regime was interrupted for measuring $\mathrm{CO}_{2}$ production and leachate $\mathrm{pH}$. LAF reactors were incubated statically without aeration and closed lid. The moisture in the material was maintained by periodically returning the leachate collected in the liquid traps back into the composting mix and by sprinkling with tap water. After 71 days, the material from each reactor was emptied into another container, thoroughly hand-mixed with gardening tools, and subsampled for analyses.

Before vermicomposting, the reactors were mixed and sampled and left open for 2 weeks to compost at room temperature without forced aeration to increase $\mathrm{pH}$ and remove some of the $\mathrm{NH}_{3}$. Thereafter, 150 red wiggler worms (Eisenia fetida), provided by industrial waste treatment and recycling facility Lindum, Drammen (Norway), were placed in each reactor. The reactors were kept moist and open and at room temperature $\left(23^{\circ} \mathrm{C}\right)$. After 77 days, the material from each reactor was emptied in another container, the earthworms
Fig. 1 Schematic representation of the composting reactor setup. a When the pump is working. b When closed and connected to the $\mathrm{CO}_{2}$ analyzer

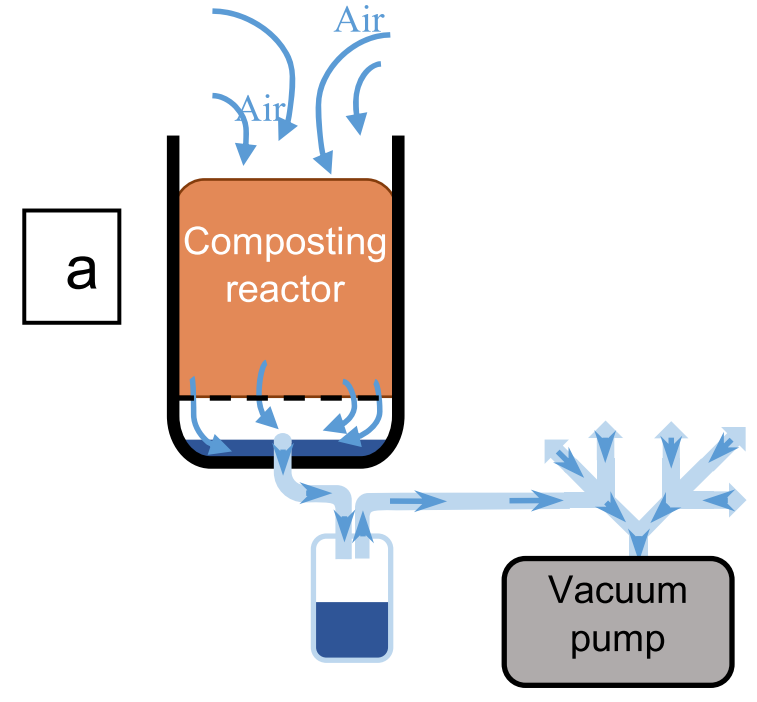

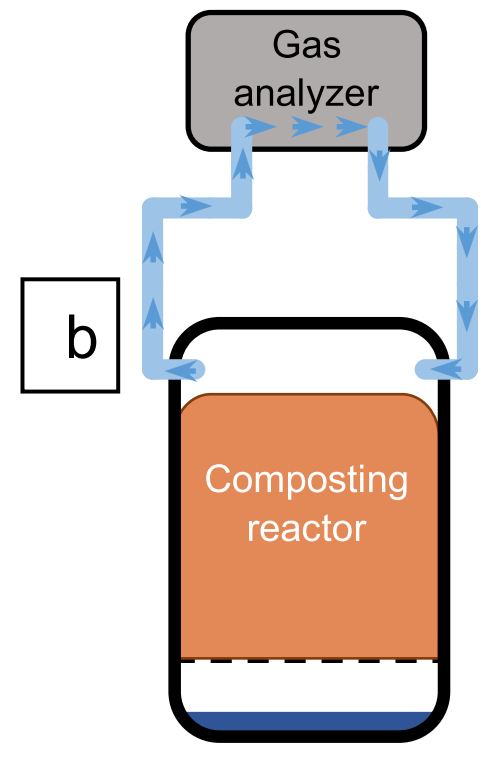


Initial substrate sample - physicochemical characteristics, pharmaceuticals

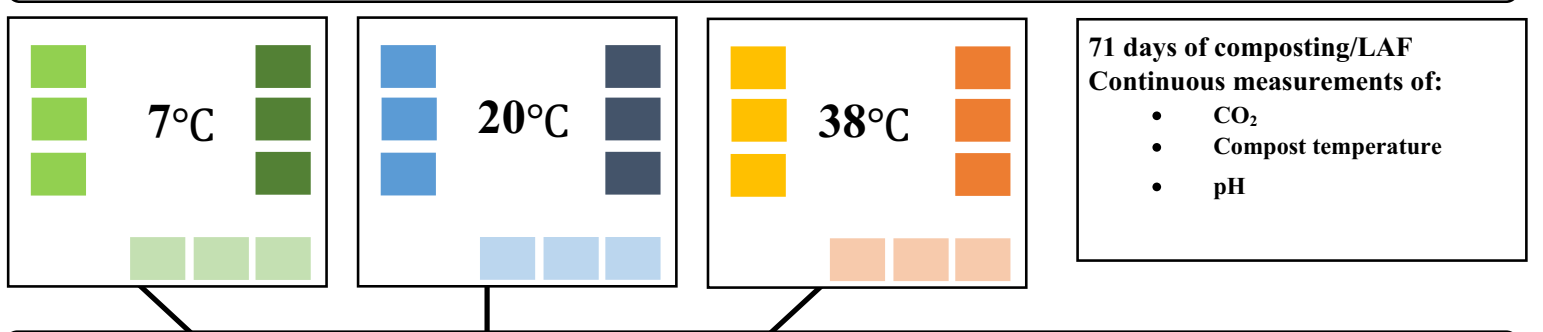

Analysis of physicochemical characteristics, fecal indicators, pharmaceuticals

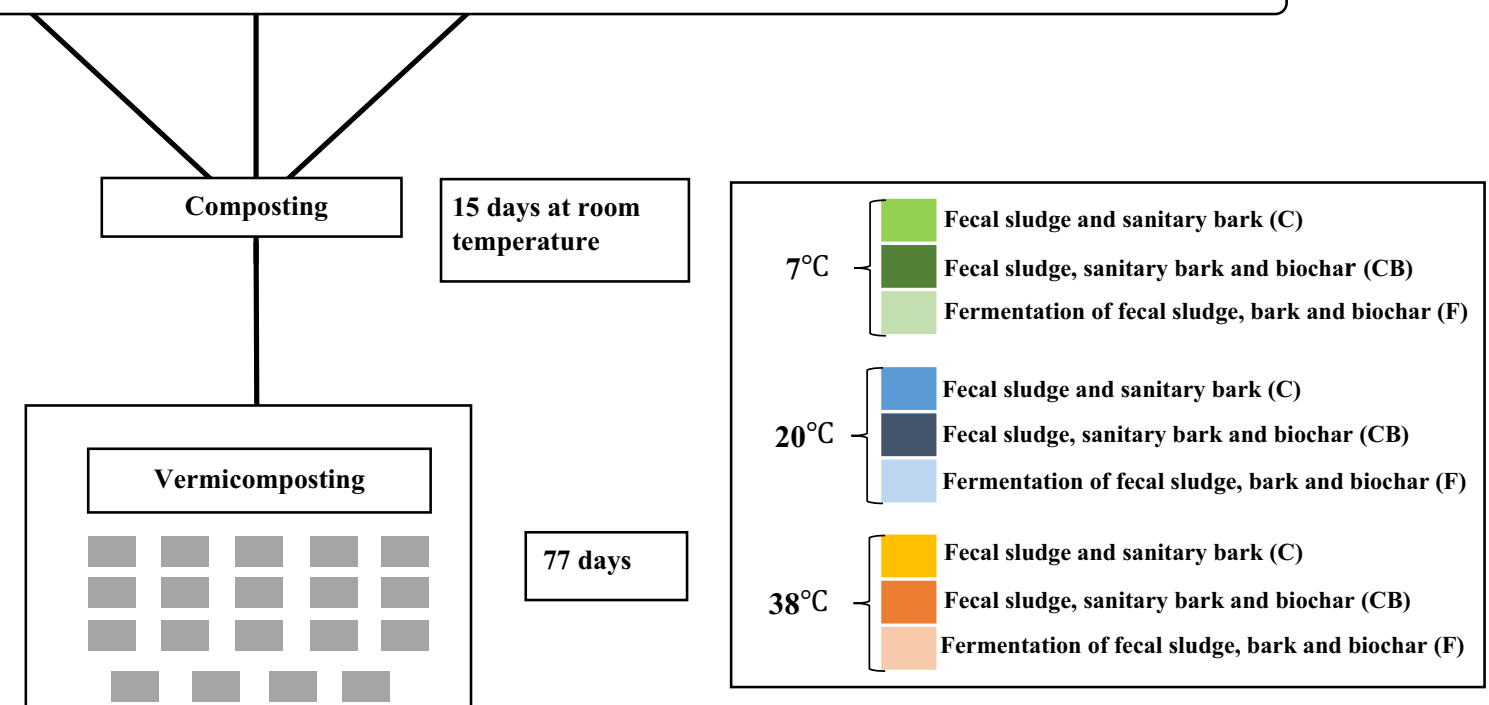

Analysis of physicochemical characteristics and fecal indicators

Fig. 2 Overview of the experimental setup, treatments, and sampling timeline

were counted and removed, and the material was thoroughly mixed with gardening tools and sampled. The method of counting did neither differentiate between development stages of the earthworms nor include eggs.

Table 1 Initial substrate composition presented as average wet weight per reactor

\begin{tabular}{llll}
\hline & $\begin{array}{l}\text { Fecal matter and } \\
\text { sanitary bark } \\
(\mathrm{C})\end{array}$ & $\begin{array}{l}\text { Fecal matter, sanitary bark, } \\
\text { and biochar } \\
\text { (CB) }\end{array}$ & $\begin{array}{l}\text { Fecal matter, sanitary bark, and } \\
\text { biochar, for fermentation } \\
\text { (F) }\end{array}$ \\
\hline Fecal material (kg) & 3.2 & 3 & 3.2 \\
Sanitary bark (kg) & 1.7 & 1.6 & 1.4 \\
Compost inoculant (kg) & 0.13 & 0.13 & 0 \\
Urine (L) & 0.75 & 0.75 & 0.7 \\
Water (L) & 0.5 & 0.47 & 0.25 \\
Biochar (kg) & - & 0.28 & 0.3 \\
Lactic acid bacteria inoculant - sauerkraut juice (L) & - & - & 0.3 \\
Total (kg) & 6.3 & 6.2 & 6.25 \\
\hline
\end{tabular}




\section{Initial mixtures and materials}

The initial substrates and corresponding amounts per reactor are listed in Table 1. The fecal material used for the experiment was mixed with small amounts of toilet paper and residues from sanitary pads and wet wipes. It was acquired from one collection compartment servicing five dry toilets at Åstjern cabin complex, Bleiken, Norway. The fecal sludge was accumulated over 2 years with daily fresh inputs until the day of collection. Separately collected urine was added to the mixture for mimicking fresh input to a dry toilet. The urine was obtained from a nearby farm household, collected, and stored in closed containers prior to use in this experiment. Bark was used as a bulking material to adjust the $\mathrm{C} / \mathrm{N}$ ratio (based on preliminary tests with the materials) and to improve the structure. The bark was from commercially available packs of sanitary bark (Nordic Garden, Steinsholt, Norway) consisting of finely cut $(0-15 \mathrm{~mm})$ coniferous bark. It is commonly marketed and used as a dry toilet amendment in Scandinavia. Compost from a preliminary trial with fecal matter, bark, and food waste was used as inoculant. In the biochar treatments (Mix CB and Mix F), biochar - collected from a Pyreg pilot pyrolysis plant (established as part of the Stockholm Biochar Project (2017), and using garden waste as a substrate for the process) - was added to the substrate mix. The amount was corresponding to approximately $5 \%$ of the volume of the corresponding mixture. For the lactic acid fermentation treatment (Mix F), the substrate was inoculated with sauerkraut juice, instead of compost and biochar added, as in the Terra Preta sanitation concept (De Gisi et al. 2014). Sauerkraut is a widely available LAF product in Europe and had already been reported as inoculant for fermentation of feces (Andreev et al. 2016, 2017). The sauerkraut juice was drained from a mix from homemade and commercially available sauerkraut. Each substrate was combined and mixed in a cement mixer (Atika, model Comet $130 \mathrm{~S}$, Ahlen, Germany) in two batches of 25-30 L and then distributed to the nine reactors for each treatment (Table 1). An initial substrate sample was taken from each reactor for chemical analysis.

\section{Microbial activity in the composting treatments}

The microbial activity during composting was followed by monitoring temperature continuously and by measuring respiration. Temperature was recorded with a HOBO Pendant Temperature Data Logger (Onset, Bourne, USA, $0.5^{\circ} \mathrm{C}$ accuracy). The loggers were buried in the center of the composting mix and remained there for the 71 days of treatment, logging at intervals of $10 \mathrm{~min}$. Respiration was measured as $\mathrm{CO}_{2}$ accumulation in the reactor headspace using a portable $\mathrm{CO}_{2}$ infrared gas analyzer (EGM-5, PP-Systems, Amesbury, USA, dynamic range 0-100,000 ppm). Pump power and airflow rate were set to maximum, resulting in a circulating headspace airflow of ca. $0.5 \mathrm{~L} \mathrm{~min}^{-1}$. To measure respiration, the gas analyzer was sequentially connected to each reactor while keeping the lock closed (Fig. 1b). To determine the respiration rate, $\mathrm{CO}_{2}$ concentrations were recorded every $10 \mathrm{~s}$ for at least $6 \mathrm{~min}$. The $\mathrm{CO}_{2}$ measurements were carried out daily during the first 15 days of composting and every second day for the remainder of the 71-day treatment period. Preliminary composting trials with a similar reactor, substrate volume, and substrate mixture showed that the highest activity occurred within the first 5 to 10 days.

The $\mathrm{CO}_{2}$ production rate was estimated from the increase of $\mathrm{CO}_{2}$ concentration over time by linear regression of on average $200 \mathrm{~s}$ from the middle of the 6-min measurement period and expressed as mg $\mathrm{CO}_{2}-\mathrm{C}$ reactor $^{-1}$ day $^{-1}$ using Eq. 1:

$m g \mathrm{CO}_{2}-$ Creactor $^{-1}$ hour $^{-1}=\frac{\mathrm{ppmCO}_{2} \mathrm{~s}^{-1} \times 10^{-6} \times \mathrm{V}}{\mathrm{Vm} \times \mathrm{M} \times 3600 \times 1000}(1)$

where ppm $\mathrm{CO}_{2} \mathrm{~s}^{-1}$ is the change in $\mathrm{CO}_{2}$ concentration, $V$ is the volume of the headspace $(L), V_{\mathrm{m}}$ is the molar volume (L $\mathrm{mol}^{-1}$ ) at each temperature, and $M$ is the molecular weight of $\mathrm{C}$ in $\mathrm{CO}_{2}\left(12 \mathrm{~g} \mathrm{~mol}^{-1}\right)$.

Active degradation reduces the volume of the material with time. To account for the resulting increase in headspace volume, $V$ was estimated based on the difference between the level of the material in the reactor and the lid at Day 1 and Day 71 . The composting period was divided into 3 periods based on observations and confirmed by temperature and $\mathrm{CO}_{2}$ measurement: first, a period of intensive degradation - Day 1 to Day 5 , then a period of active degradation - Day 6 to Day 20 , and, finally, period of low activity - Days 21 to 71 . The headspace volume was adjusted accordingly.

The total amount of $\mathrm{C}$ respired during composting was derived for each replicate by cumulating the average of each two adjacent measurements before averaging the values per treatment. The amount of cumulatively respired $\mathrm{CO}_{2}-\mathrm{C}$ was expressed per $\mathrm{kg}$ initial $C$ in each reactor.

\section{Fecal indicators}

The fecal indicators in the treatments were assessed by enumerating Escherichia coli and enterococci in composite samples taken in duplicates after the composting/fermentation and after the vermicomposting. The samples were stored at approximately $4^{\circ} \mathrm{C}$ and analyzed within $78 \mathrm{~h}$ of collection. A subsample of $10 \mathrm{~g}$ was diluted in $90-\mathrm{mL}$ maximum recovery diluent (purchased from Sigma-Aldrich), and the mix was mechanically homogenized by a stomacher for $2 \mathrm{~min}$. Preliminary samples from each treatment were used to determine the number of dilutions. They were further analyzed according to the method for the enumeration of $E$. coli by a defined substrate most probable number (MPN) technique 
(APHA 2005) using Colilert 18 test kits (IDEXX Laboratories Inc., Westbrook, ME, USA). The cell numbers were determined according to the IDEXX Quanti-Tray/2000 MPN table and expressed per $\mathrm{g}$ of dry solid.

\section{Physicochemical characteristics}

Samples were collected from each container after 71 days of composting and after 77 days of vermicomposting. The material from each reactor was emptied into a larger container and thoroughly mixed with gardening tools before sampling. Dry matter and moisture content were determined by drying the samples at $60^{\circ} \mathrm{C}$ for $48 \mathrm{~h}$. Volatile solids (VSs) were determined by combustion of dry samples at $500^{\circ} \mathrm{C}$ for $3-4 \mathrm{~h}$ in a muffle furnace. Total $\mathrm{C}$ was determined in crushed samples by dry combustion (Nelson and Sommers 1982) at $1050^{\circ} \mathrm{C}$ using a Leco CHN-1000 instrument (St. Joseph, Michigan, USA). Total $\mathrm{N}$ was measured on the same instrument according to the Dumas method (Bremner and Mulvaney 1982). Ammonium $\left(\mathrm{NH}_{4}-\mathrm{N}\right)$ was measured by flow injection analysis (FIA, Tecator FIAstar 5010 Analyzer, Hillerød, Denmark) after extraction with $2 \mathrm{M} \mathrm{KCl}$ in both fresh and dry samples. The difference in the concentration of $\mathrm{NH}_{4}-\mathrm{N}$ between fresh and dry samples was used to correct the tot $\mathrm{N}$ for the $\mathrm{NH}_{4}-\mathrm{N}$ loss as $\mathrm{NH}_{3}$ during drying. The $\mathrm{pH}$ was measured in leachate during the composting and at Day 77 of vermicomposting with a $\mathrm{pH}$ electrode (Orion ${ }^{\mathrm{TM}} \mathrm{ROSS}$ Ultra, Thermo Fisher Scientific, Waltham, USA). pH was measured in solid samples with a wet sample to water volume ratio of $1: 1.5$. For the fermentation treatments, no leachate was collected because they were not subjected to aeration and did not require additional watering. Therefore, the $\mathrm{pH}$ was not monitored regularly but only measured twice during the first 10 days.

\section{Pharmaceuticals}

For the quantification of targeted analytes in this study, a previously optimized analytical method was adopted with some modifications (Ali et al. 2019). The selection of the compounds (see Online Resource, Table S1) was based on their high rates of production and prescription in addition to their frequent detection in contaminated environmental samples in Norway.

Samples were prepared as described in Online Resource (S3) from initial mixtures and the products of composting/fermentation and analyzed with liquid chromatography-tandem mass spectrometry (see Online Resource, S4). The method performance characteristics are listed in Online Resource, Table S3 and described in S5.

\section{Statistics}

Analysis of variance was used to compare the effects of the different treatments on the measured physicochemical characteristics. The assumptions were checked with Levene's test for homogeneity of variances and the Shapiro-Wilk test for normality. Two-way ANOVA was used when the assumptions were met. To evaluate differences of means per factor, the ANOVA was followed by Tukey's post hoc comparison of means $(p<0.5)$. The normality assumption was violated for concentrations of total $\mathrm{N}$ and $\mathrm{NH}_{4}-\mathrm{N}$ after vermicomposting, and the data were log transformed. For VS, $\mathrm{NH}_{4}-\mathrm{N}$, and $\mathrm{pH}$ after composting and VS and total C after vermicomposting, the Kruskal-Wallis rank sum test was used for analysis. Differences between cumulative C-mass losses between the composting with and without biochar and initial and posttreatment concentrations of pharmaceutical compounds were evaluated with one-tail, unequal variance t-test. Statistical analyses were carried out using the R statistical package version 1.3.959 under the GNU public license (Boston, MA, USA).

\section{Results}

\section{Effect of temperature on the composting process}

Microbial activity during the 71 days of composting was monitored as temperature change and $\mathrm{CO}_{2}$ production. Figure 3 shows the temperature profile for all treatments for the first 38 days of composting. The periodical fluctuations (positive in $7^{\circ} \mathrm{C}$ and negative in $38^{\circ} \mathrm{C}$ treatments) correspond to the time when the reactors were taken out of the climate-controlled room for weighing and $\mathrm{pH}$ measurements. In all treatments, the material was self-heated and maintained higher than ambient temperature during the first 6 to 10 days, but self-heating relative to ambient temperature was clearly larger at 38 than 7 and $20^{\circ} \mathrm{C}$. The temperature profile shows clear differences between the treatments subjected to low, middle, and high ambient temperature; adding approx. 5\% biochar to the mix had no effect on the released metabolic heat.

The $\mathrm{CO}_{2}$ evolution rates for composting treatments are shown in Fig. 4 (top). Similarly to the temperature profile, highest $\mathrm{CO}_{2}$ production was detected during the first 5 days before levelling gradually off and stabilizing after 30-40 days of composting. At $38^{\circ} \mathrm{C}$, microbial activity was highest, and the $\mathrm{CO}_{2}$ production rates remained above those of other temperature treatments throughout the entire period. Maximum observed respiration rates were $463-707 \mathrm{mg} \mathrm{CO}_{2}-\mathrm{C}_{\text {reactor }}{ }^{-1}$ $\mathrm{h}^{-1}$ on Day 2 for the $38^{\circ} \mathrm{C}$ treatment, $254-422 \mathrm{mg} \mathrm{CO}-\mathrm{C}$ reactor ${ }^{-1} \mathrm{~h}^{-1}$ on Day 3 for the $20^{\circ} \mathrm{C}$ treatment, and $100-146$ mg CO $2_{2}-\mathrm{C}_{\text {reactor }}{ }^{-1} \mathrm{~h}^{-1}$ on Day 2 for the $7^{\circ} \mathrm{C}$ treatment. The highest ambient temperature resulted in the highest $\mathrm{CO}_{2}$ 


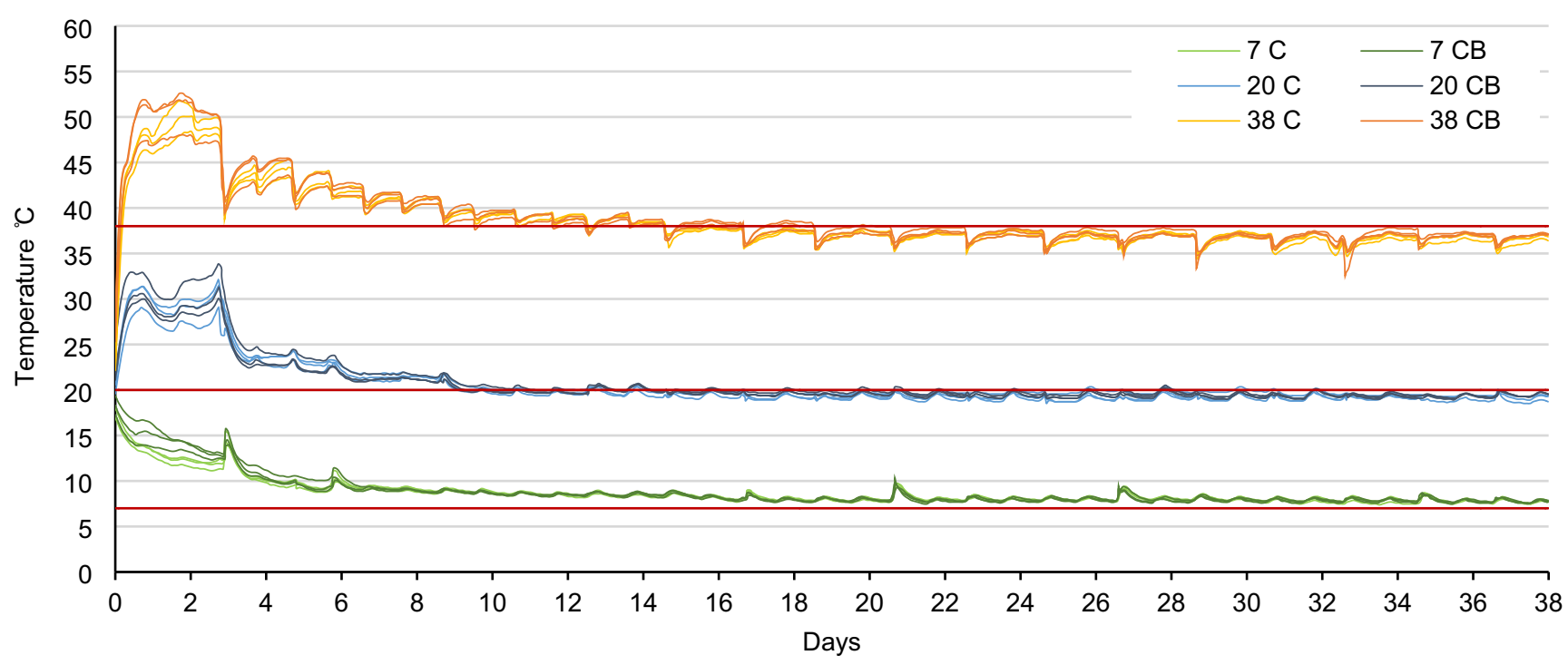

Fig. 3 Temperature profile measured in the center of each reactor for the first 38 days of composting. The red lines represent the ambient temperature in the climate-controlled rooms $-7,20$, and $38^{\circ} \mathrm{C}$. C composting, $\mathrm{CB}$ composting with addition of biochar

production. There was no indication that the addition of biochar affected rates or dynamics of $\mathrm{CO}_{2}$ production.

The cumulative $\mathrm{CO}_{2}-\mathrm{C}$ loss varied from 45.6 to $177.6 \mathrm{~g} \mathrm{C}$ $\mathrm{kg}^{-1} \mathrm{C}$ across treatments. Ambient temperature had a strong effect on the relative amount of respired $\mathrm{C}$, whereas the addition of biochar lowered respiration losses only insignificantly (Fig. 4 bottom). Two to three times more $\mathrm{C}$ was respired at $38^{\circ} \mathrm{C}$ than at $7^{\circ} \mathrm{C}$ after 69 days. The $38^{\circ} \mathrm{C}$ treatment also had the steepest initial increase in cumulative respiration, emitting half of the totally respired $\mathrm{C}$ within 9 days, whereas 12 (without biochar) and 11 days (with biochar) were needed at $20^{\circ} \mathrm{C}$ and 18 and 16 days at $7^{\circ} \mathrm{C}$.

\section{Physicochemical characteristics}

The physicochemical characteristics in the initial mixtures suggested that the materials were well-suited as a feedstock for active composting (Table 2). The $\mathrm{C} / \mathrm{N}$ ratios in the initial mixtures corresponded to a ratio that facilitates active degradation (Epstein 1997) with little recalcitrant carbon materials as indicated by the high content of VS. The moisture content was at the higher limit of what is considered optimal for composting, 4070\% (Guo et al. 2012). The $\mathrm{pH}$ was alkaline.

The 71 days of treatment affected physicochemical properties differently in fermentation and composting treatments. The fermentation treatment resulted in a significantly higher $\mathrm{C} / \mathrm{N}$ and $\mathrm{NH}_{4}-\mathrm{N}$ content, whereas no significant change was observed in the composting treatments. Clear differences between the treatments were observed in the $38^{\circ} \mathrm{C}$ composting treatments with lower $\mathrm{C} / \mathrm{N}$ ratios, higher concentration of tot $\mathrm{N}$, and lower VS. Furthermore, the $\mathrm{pH}$ in the leachate of $38 \mathrm{C}$ and $38 \mathrm{CB}$ decreased, which was not observed in the other treatments and indicates a chemical transition in the material that started around Day 57 (Fig. 5).

For the fermentation treatments, the $\mathrm{pH}$ was not followed continuously but was measured in leachate on Day 5 for $7 \mathrm{~F}$ as 4.5 and $20 \mathrm{~F}$ as 3.8 and on Day 9 as 4.3 for $7 \mathrm{~F}$ and 3.9 and 5.7 for two of the replicates in $20 \mathrm{~F}$. The acidity in the leachate indicated successful inoculation with lactic acid bacteria and production of lactic acid in the first days. By contrast, the $\mathrm{pH}$ measured in the samples taken on day 71 indicated that the acidity was not maintained throughout the entire treatment period.

For the composting treatments, the changes of the $\mathrm{pH}$ in the leachate are plotted in Fig. 5. There was little change in the $7^{\circ} \mathrm{C}$ treatments. In the $20^{\circ} \mathrm{C}$ treatments, the $\mathrm{pH}$ decreased around Day 30 and returned back to neutral $\mathrm{pH}$ after about 20 days. This transient acidification was more pronounced in the compost without than with biochar. The $\mathrm{pH}$ in $38^{\circ} \mathrm{C}$ treatments was relatively stable throughout but started to decline during the last days of composting, i.e., after Day 57. The addition of biochar did not result in clear $\mathrm{pH}$ differences. However, in the $7^{\circ} \mathrm{C}$ and $20^{\circ} \mathrm{C}$ treatments, it resulted in slightly higher $\mathrm{pH}$, whereas at $38^{\circ} \mathrm{C}$, it resulted in lower $\mathrm{pH}$ values at the end.

\section{Fecal indicators}

E. coli was detected in all treatments within the range of 90.6 MPN g ${ }^{-1} \mathrm{DM}$ to the upper limit of detection $>8.5 \times 10^{8}$ (Fig. 6). The smallest MPN values of $E$. coli were detected in the 38 $\mathrm{C}$ treatment. E. coli was most abundant in $7 \mathrm{C}$ and $7 \mathrm{CB}$, at the upper limit of detection and $4-6 \log _{10}$ units higher than in the other treatments. Interestingly, at $7^{\circ} \mathrm{C}$, the MPN E. coli in the fermentation was $5 \log _{10}$ units lower than in the composting treatments. 

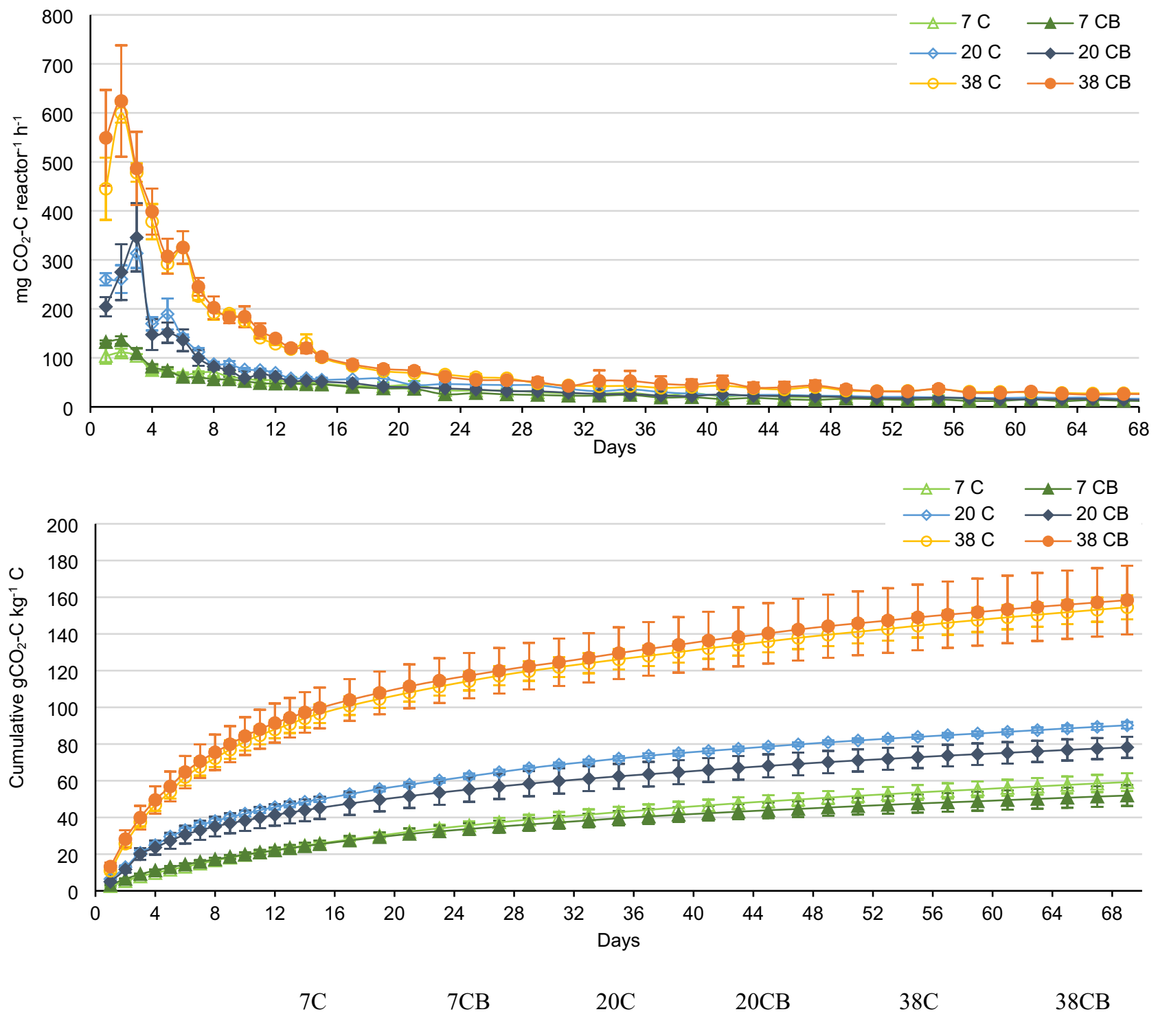

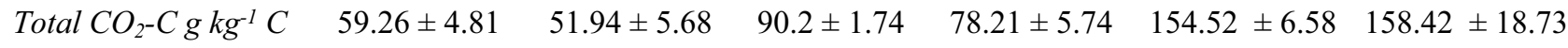

Fig. $4 \mathrm{CO}_{2}$ emission rates (top) and mean cumulative $\mathrm{CO}_{2}$ emission (bottom) $(n=3, \pm \mathrm{SD})$ during composting at three different ambient temperatures $\left(7,20\right.$, and $\left.38^{\circ} \mathrm{C}\right)$. C composting, $\mathrm{CB}$ composting with addition of biochar. Cumulative $\mathrm{CO}_{2}$ emission estimation is based on periodic

Enterococci were detected in high numbers in all treatments (Fig. 6). The concentration varied with temperature with higher numbers at $7^{\circ} \mathrm{C}$ and $20^{\circ} \mathrm{C}$ and comparatively lower numbers at $38^{\circ} \mathrm{C}$. The values for the $7^{\circ} \mathrm{C}$ and $20^{\circ} \mathrm{C}$ treatments were in the range of $6.4 \times 10^{4}-1.9 \times 10^{7} \mathrm{MPN}$ enterococ$\mathrm{ci}$, whereas the treatments at $38^{\circ} \mathrm{C}$ had lower numbers in the range of $3.0 \times 10^{4}-1.3 \times 10^{6}$.

For both $E$. coli and enterococci, the higher temperature treatments resulted in lower numbers. There was no clear effect of adding biochar on the abundance of fecal indicators.
$\mathrm{CO}_{2}$ production measurements in the headspace and adjusted for initial total $\mathrm{C}$. The average values with standard deviations for three replicates for total cumulative $\mathrm{CO}_{2}-\mathrm{C} \mathrm{g} \mathrm{kg}^{-1} \mathrm{C}$ are given below in the table

The fermentation treatments showed variable results depending on temperatures and had significantly lower numbers of E. coli after LAF at $7^{\circ} \mathrm{C}$ compared to composting at the same temperature.

\section{Fate of pharmaceutical compounds}

The pharmaceutical compounds were selected based on their relatively high prescription rates in Norway, and their pattern and concentrations reflect the regional consumption and are 
Table 2 Physicochemical characteristics for the initial mixtures and after 71 days of composting/fermentation. The data are means $(n=3)$ and standard deviation. Capital " $T$ " indicates means that are significantly different due to effect of temperature and capital "M" due to mixtures. Note: $\mathrm{pH}$ values measured in samples

\begin{tabular}{|c|c|c|c|c|c|c|c|c|}
\hline & & Moisture \% & VS $\%$ & $\mathrm{pH}$ & Tot. C \% & Tot. N \% & $\mathrm{C} / \mathrm{N}$ & $\mathrm{NH}_{4}-\mathrm{N} \mathrm{mg} \mathrm{g}{ }^{-1}$ \\
\hline \multirow[t]{3}{*}{ Initial } & Mix C & $68 \pm 0.5$ & $89 \pm 0.3$ & 8.4 & $48 \pm 0.25$ & $1.83 \pm 0.00$ & $26 \pm 0.1$ & 2.802 \\
\hline & Mix CB & $68 \pm 0.1$ & $89 \pm 0.4$ & 8.5 & $49.5 \pm 0.85$ & $1.93 \pm 0.04$ & $26 \pm 0.1$ & 3.435 \\
\hline & Mix F & $69 \pm 1.5$ & $89 \pm 0.2$ & 8.2 & $50.3 \pm 0.57$ & $1.87 \pm 0.07$ & $27 \pm 1.3$ & 4.61 \\
\hline \multirow[t]{10}{*}{ After composting/fermentation } & $7 \mathrm{C}$ & $70 \pm 1.8$ & $88 \pm 0.2$ & 7.2 & $47.6 \pm 0.24^{\mathrm{M}}$ & $1.78 \pm 0.15$ & $27 \pm 2.5$ & $0.862 \pm 0.031$ \\
\hline & $7 \mathrm{CB}$ & $72 \pm 0.7$ & $89 \pm 0.3$ & 7.2 & $49.6 \pm 0.58$ & $1.83 \pm 0.02$ & $27 \pm 0.1$ & $0.791 \pm 0.050$ \\
\hline & $7 \mathrm{~F}$ & $66 \pm 0.4$ & $89 \pm 0.1$ & 6.8 & $51.6 \pm 0.58$ & $1.83 \pm 0.08^{\mathrm{M}}$ & $28 \pm 1.1^{\mathrm{M}}$ & $3.905 \pm 0.051$ \\
\hline & $20 \mathrm{C}$ & $71 \pm 0.6$ & $89 \pm 2.6$ & 7.1 & $47.6 \pm 0.33^{\mathrm{M}}$ & $1.76 \pm 0.06$ & $27 \pm 1.1$ & $0.101 \pm 0.063$ \\
\hline & $20 \mathrm{CB}$ & $70 \pm 0.6$ & $86 \pm 1.0$ & 7.2 & $49.4 \pm 0.60$ & $1.82 \pm 0.06$ & $27 \pm 0.7$ & $0.093 \pm 0.022$ \\
\hline & $20 \mathrm{~F}$ & $67 \pm 0.1$ & $89 \pm 0.5$ & 6.8 & $49.9 \pm 0.42$ & $1.81 \pm 0.03^{\mathrm{M}}$ & $28 \pm 0.7^{\mathrm{M}}$ & $4.118 \pm 0.292$ \\
\hline & $38 \mathrm{C}$ & $69 \pm 0.4$ & $85 \pm 0.7$ & 7.3 & $46.8 \pm 0.10^{\mathrm{M}}$ & $2.28 \pm 0.05^{\mathrm{T}}$ & $21 \pm 0.5^{\mathrm{T}}$ & $0.867 \pm 0.145$ \\
\hline & $38 \mathrm{CB}$ & $69 \pm 1.3$ & $79 \pm 3.6$ & 7 & $49.7 \pm 1.44$ & $2.19 \pm 0.04^{\mathrm{T}}$ & $23 \pm 1.1^{\mathrm{T}}$ & $0.455 \pm 0.166$ \\
\hline & $38 \mathrm{~F}$ & $67 \pm 0.8$ & $89 \pm 0.8$ & 7.5 & $49.9 \pm 0.78$ & $1.7 \pm 0.04^{\mathrm{T}, \mathrm{M}}$ & $29 \pm 1.0^{\mathrm{T}, \mathrm{M}}$ & $4.236 \pm 0.042$ \\
\hline & & & $\mathrm{K}-\mathrm{W}$ test & $\mathrm{K}-\mathrm{W}$ test & & & & $\mathrm{K}$-W test \\
\hline \multicolumn{2}{|l|}{ Temperature } & ns & - & ns & ns & $* * *$ & $* * *$ & ns \\
\hline \multicolumn{2}{|l|}{ Mix } & $* * *$ & $* * *$ & ns & $* * *$ & $* * *$ & $* *$ & $* * *$ \\
\hline \multicolumn{2}{|l|}{ Temperature $\times$ mix } & $*$ & / & / & ns & $* * *$ & $* * *$ & / \\
\hline
\end{tabular}

subject to the variability within the matrix. The fecal matter and urine used in the study are not directly comparable with fresh excreta, and the initial concentrations were expected to primarily reflect compounds that partitioned to the solids, as those excreted with urine are more soluble and could have drained away. The initial concentrations were measured in the mixtures for direct comparison of concentrations before and after treatment.

The results for ibuprofen, sulfamethoxazole, and diclofenac must be regarded as semi-quantitative due to

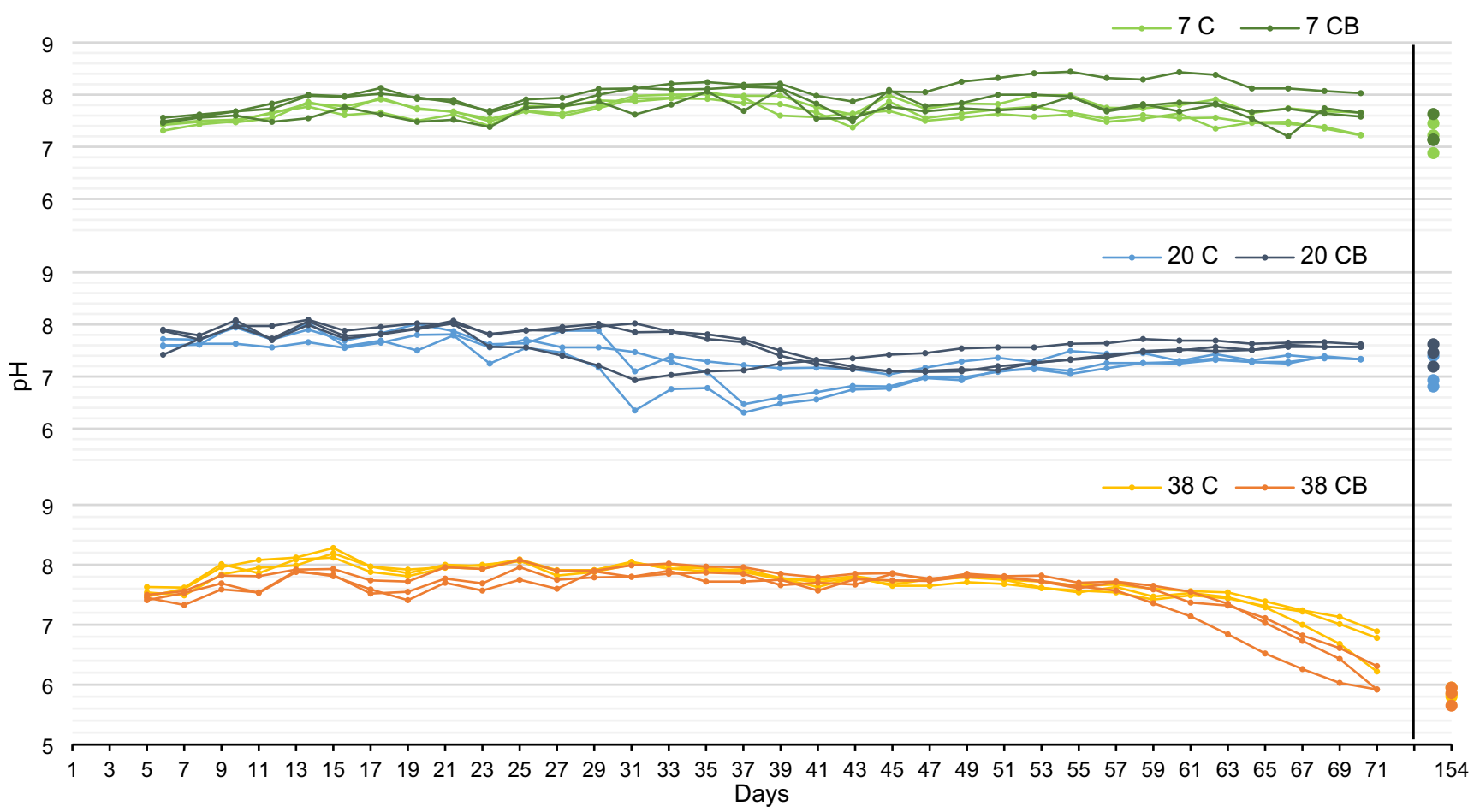

Fig. 5 Leachate $\mathrm{pH}$ throughout 71 days of composting at 7, 20, and $38^{\circ} \mathrm{C}$ and on the final day of vermicomposting - Day 154 . C composting material without biochar, $\mathrm{CB}$ composting with addition of biochar 

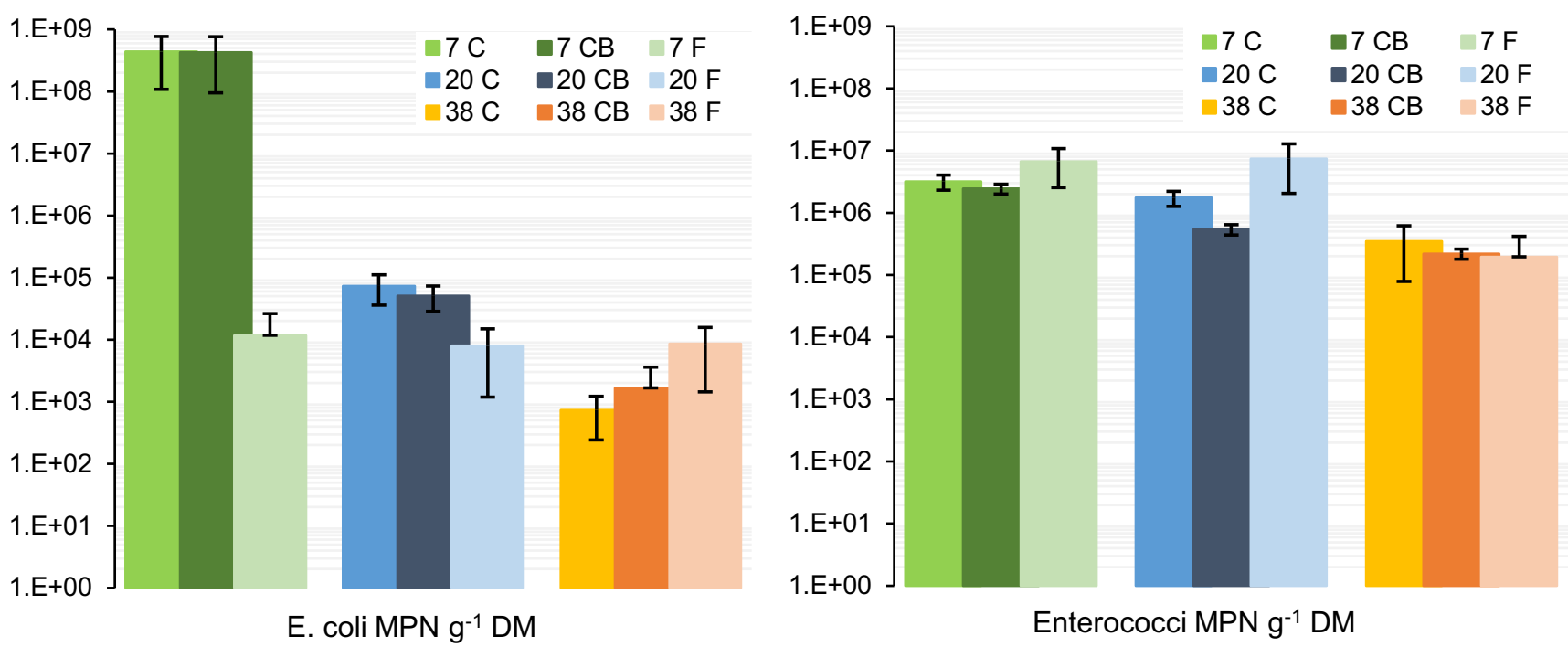

Fig. 6 Enumeration of the indicator organisms $E$. coli (left) and enterococci (right) in samples after composting/fermentation at 7,20 , and $38^{\circ} \mathrm{C}$ ambient temperature. $\mathrm{C}$ composting, $\mathrm{CB}$ composting with addition of biochar. The error bars represent standard deviation

unreliable recoveries (see Online Resource, S5). The highest initial concentration among the detected pharmaceutical compounds was ibuprofen with a range of $8113-16551 \mu \mathrm{g} \mathrm{kg}^{-1}$. Ibuprofen was not detected in any of the composting products, but in the fermentation products, it was in the range of $93-212$ $\mu \mathrm{gg}^{-1}$. Sulfamethoxazole was detected in 7 out of 9 initial samples within the range of $3.5-11.7 \mu \mathrm{g} \mathrm{kg}^{-1}$ and after treatment only in 5 out of 27 samples in a range of $0.2-21.1 \mu \mathrm{g}$ $\mathrm{kg}^{-1}$. Where detected in the products, amounts were lower than the initial values, with one exception where the concentration was $21.1 \mathrm{\mu g} \mathrm{kg}^{-1}$ (one of the $20 \mathrm{BC}$ samples). Diclofenac showed interesting pattern and therefore is discussed alongside the other compounds.

Figure 7 shows the detected concentrations for the other eight compounds, both in the initial and post-treatment samples. Caffeine was the compound with the second highest initial concentration with a range of 1351 to $2389 \mu \mathrm{g} \mathrm{kg}^{-1}$, whereas the concentrations of warfarin were the lowest with values of 0.012 to $0.034 \mu \mathrm{g} \mathrm{kg}^{-1}$ in initial samples. For caffeine, atorvastatin, losartan, diclofenac, and warfarin, the posttreatment concentrations were strongly negatively related to temperature, indicating that the increase in temperature and/or more active composting facilitated their removal.

Larger effects were observed when comparing the composting and LAF. For caffeine, carbamazepine, metoprolol, acetaminophen, and warfarin, there was a clear trend indicating more efficient removal during composting compared with fermentation. For caffeine, the results indicate higher removal in $38 \mathrm{C}$ and $38 \mathrm{CB}$ treatments and lower in the fermentation treatments. Carbamazepine showed low reduction in all treatments, and the highest concentrations were detected in the fermentation products. Post-treatment concentrations for metoprolol, acetaminophen, and warfarin showed a clear difference between composting and fermentation with larger reduction during composting. By contrast, atorvastatin, losartan, and diclofenac were detected in lower concentrations in the fermentation products compared to the composting products.

For most compounds, there was no clear effect of adding biochar, except for carbamazepine and diclofenac, for which the detected concentrations in the $\mathrm{CB}$ treatments were lower than those in C. For carbamazepine, the lowest detected concentrations were in the $\mathrm{CB}$ treatment.

The removal within the different treatments is shown in Fig. 8 but should be interpreted with caution due to the high variation in the concentrations detected between the replicates. Statistically significant reduction in concentrations between initial and after treatment was found only in some treatments for caffeine, metoprolol, losartan, and atorvastatin (Fig. 8, with *). Diclofenac and warfarin are not plotted as they were detected in higher concentrations after treatment with some exceptions for the treatments at $38^{\circ} \mathrm{C}$. Also, losartan was detected in $7 \mathrm{CB}$ and $20 \mathrm{CB}$ at higher average concentrations. Likewise, carbamazepine and metoprolol concentrations increased in the fermentation treatment products. This can be explained by cleaving back of conjugates or by change in efficiency of extraction due to changes in the chemical conditions and degradation of particles to which they may have been adsorbed to initially (Leclercq et al. 2009; Jewell et al. 2014).

\section{Vermicomposting}

Vermicomposting further stabilized and conditioned the composing/fermentation products. The resulting material was visually similar to conventional vermicompost with no unpleasant odors. The stabilization was also evident from 

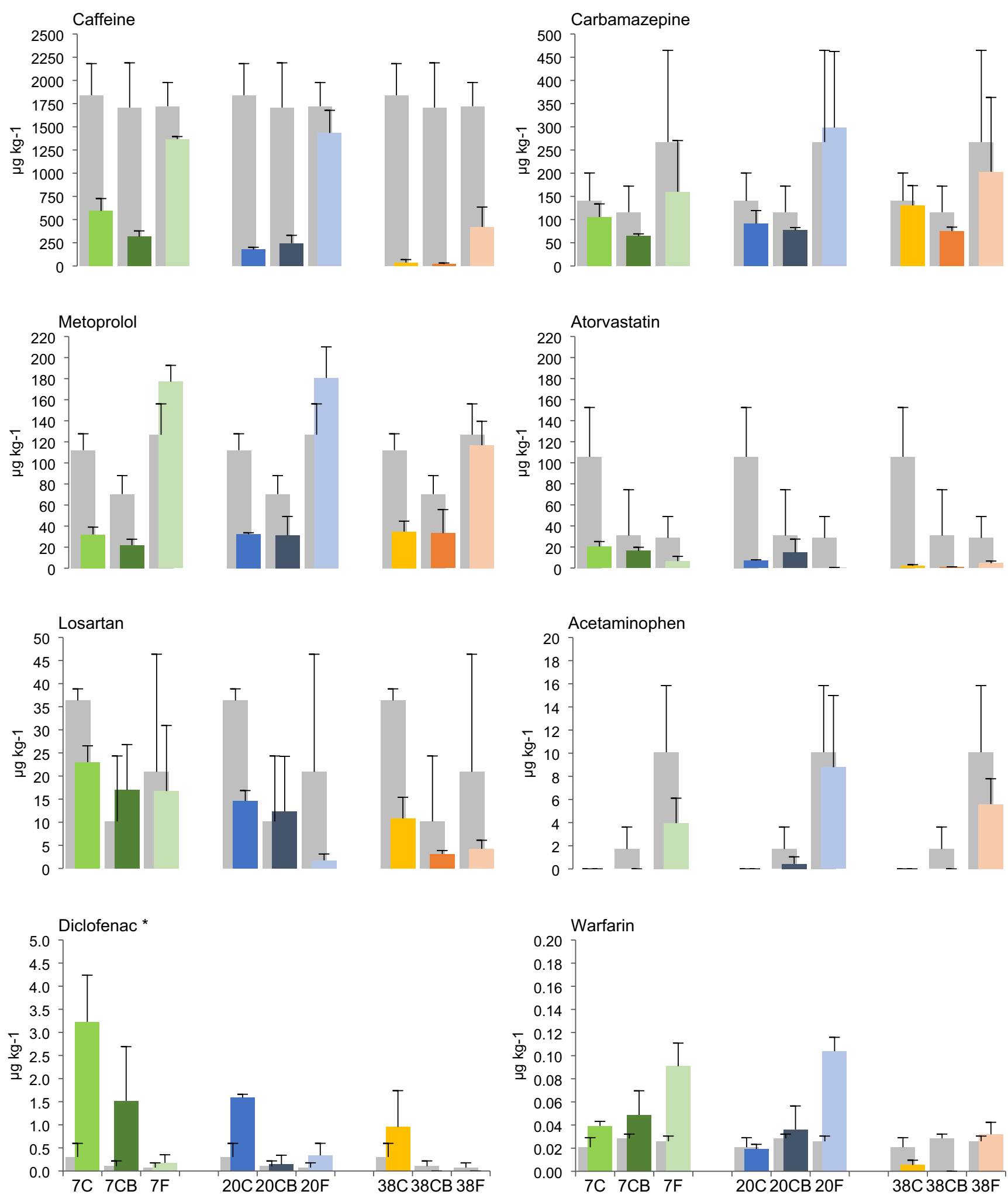

Fig. 7 Comparison of caffeine, carbamazepine, metoprolol, atorvastatin, losartan, acetaminophen, diclofenac, and warfarin concentrations in the initial mixtures (gray columns) and after 71 days of composting/

the significantly lower VS\% and $\mathrm{NH}_{4}-\mathrm{N}$ content (Table 3) than before vermicomposting.

The physicochemical parameters after vermicomposting differed between the treatments, but followed similar patterns 


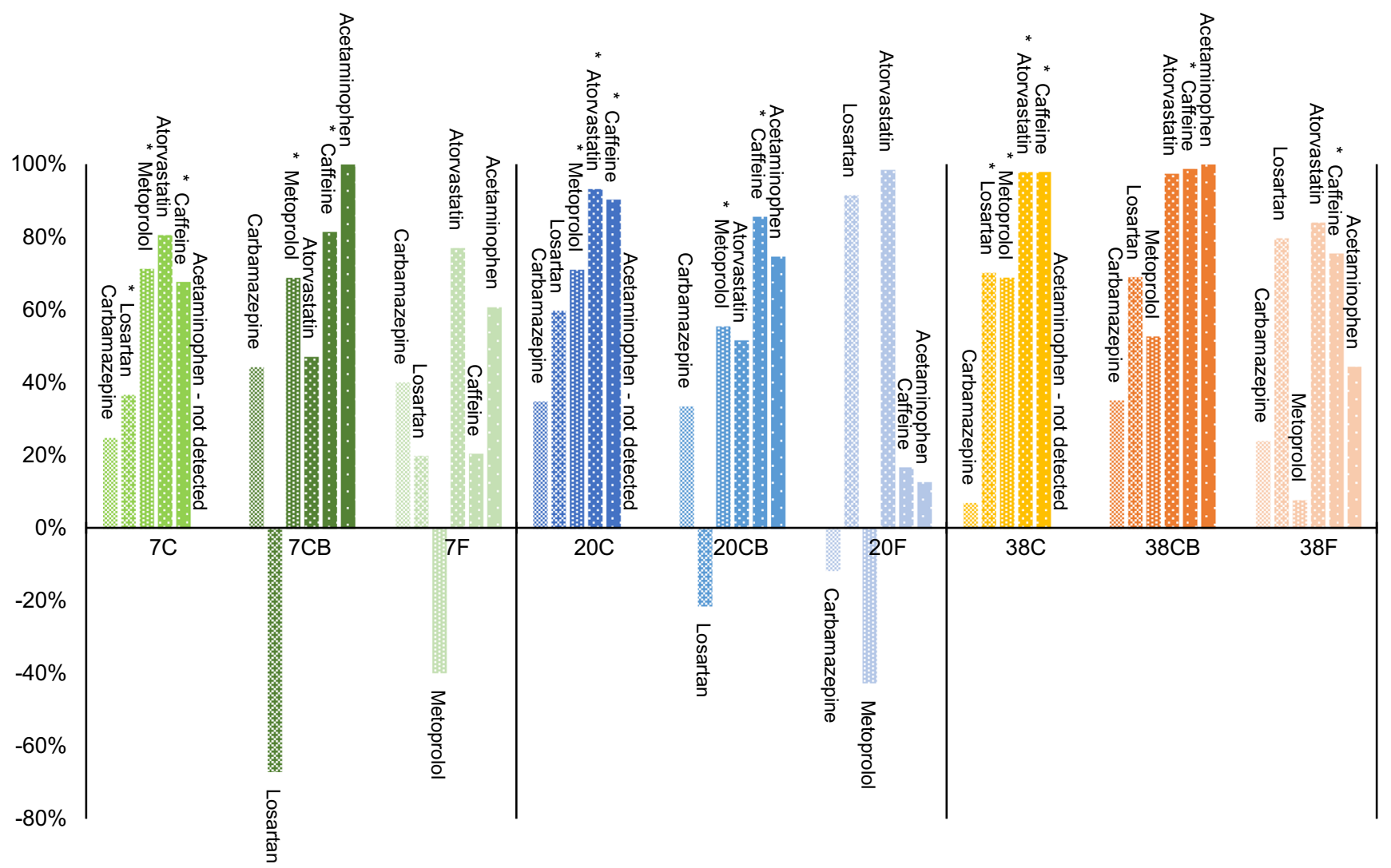

Fig. 8 Removal of carbamazepine, losartan, metoprolol, atorvastatin, caffeine, and acetaminophen (in $\%$ of initial) after 71 days of composting/fermentation at 7,20 , and $38^{\circ} \mathrm{C}$. The asterisk indicates the

as those seen after composting/fermentation. The $\mathrm{NH}_{4}-\mathrm{N}$ concentration was still significantly higher in the previously

Table 3 Mean physicochemical characteristics $(n=3, \pm \mathrm{SD})$ for treatments after vermicomposting. The treatment factor refers to differences before and after vermicomposting. Capital " $\mathrm{T}$ " indicates cases in which T-test showed statistically significant removal at $p>0.05$. C composting, $\mathrm{CB}$ composting with addition of biochar, $\mathrm{F}$ lactic acid fermentation

fermented vermicompost than in the previously composted treatments, but on a lower level. Only the highest temperature

means that are significantly different to the rest due to effect of temperature and capital "M" due to mixtures. Note: $\mathrm{pH}$ values measured in samples

\begin{tabular}{|c|c|c|c|c|c|c|c|}
\hline & Moisture \% & VS \% & $\mathrm{pH}$ & Tot. C \% & Tot. N \% & $\mathrm{C} / \mathrm{N}$ & $\mathrm{NH}_{4}-\mathrm{N} \mathrm{mg} \mathrm{g}^{-1}$ \\
\hline $7 \mathrm{C}$ & $69 \pm 0.6$ & $87 \pm 1.2$ & 7.3 & $46.6 \pm 0.51$ & $1.98 \pm 0.39$ & $25 \pm 3.2$ & $0.026 \pm 0.005$ \\
\hline $7 \mathrm{CB}$ & $71 \pm 0.1$ & $85 \pm 0.9$ & 7.4 & $48.7 \pm 0.58$ & $1.7 \pm 0.01$ & $29 \pm 0.6$ & $0.024 \pm 0.004$ \\
\hline $7 \mathrm{~F}$ & $70 \pm 0.5$ & $87 \pm 0.6$ & 7.8 & $48.3 \pm 0.99$ & $1.78 \pm 0.07^{\mathrm{M}}$ & $27 \pm 1.5^{\mathrm{M}}$ & $0.033 \pm 0.002^{\mathrm{M}}$ \\
\hline $20 \mathrm{C}$ & $70 \pm 0.6$ & $87 \pm 1.1$ & 7.3 & $46.6 \pm 0.33$ & $1.67 \pm 0.01$ & $28 \pm 0.1$ & $0.02 \pm 0.003^{\mathrm{T}}$ \\
\hline $20 \mathrm{CB}$ & $70 \pm 0.2$ & $87 \pm 0.7$ & 7.4 & $48.3 \pm 0.40$ & $1.69 \pm 0.08$ & $29 \pm 1.3$ & $0.02 \pm 0.002^{\mathrm{T}}$ \\
\hline $20 \mathrm{~F}$ & $70 \pm 0.7$ & $83 \pm 2.0$ & 7.5 & $48.5 \pm 0.27$ & $1.86 \pm 0.10^{\mathrm{M}}$ & $26 \pm 1.3^{\mathrm{M}}$ & $0.04 \pm 0.007^{\mathrm{T}, \mathrm{M}}$ \\
\hline $38 \mathrm{C}$ & $68 \pm 1.0$ & $86 \pm 0.3$ & 6.3 & $45.9 \pm 0.50$ & $2.19 \pm 0.09^{\mathrm{T}}$ & $21 \pm 1.0^{\mathrm{T}}$ & $0.018 \pm 0.001$ \\
\hline $38 \mathrm{CB}$ & $68 \pm 0.7$ & $86 \pm 0.5$ & 6.4 & $47.9 \pm 0.31$ & $2.27 \pm 0.08^{\mathrm{T}}$ & $21 \pm 0.9^{\mathrm{T}}$ & $0.015 \pm 0.003$ \\
\hline \multirow[t]{2}{*}{$38 \mathrm{~F}$} & $70 \pm 0.6$ & $85 \pm 1.0$ & 7.4 & $49.9 \pm 1.43$ & $1.75 \pm 0.02^{\mathrm{T}, \mathrm{M}}$ & $28 \pm 1.1^{\mathrm{T}, \mathrm{M}}$ & $0.039 \pm 0.008^{\mathrm{M}}$ \\
\hline & & $\mathrm{K}-\mathrm{W}$ test & & $\mathrm{K}-\mathrm{W}$ test & & & \\
\hline Treatment & ns & $* * *$ & ns & $* *$ & $* *$ & $* * *$ & $* * *$ \\
\hline Temperature & $*$ & ns & $*$ & $\mathrm{~ns}$ & $* * *$ & $* *$ & $* *$ \\
\hline Mix & $* *$ & $\mathrm{~ns}$ & ns & $* * *$ & $* * *$ & $* * *$ & $* * *$ \\
\hline Temperature $\times$ mix & ns & / & $* *$ & / & $* * *$ & $* * *$ & . \\
\hline
\end{tabular}

Significance codes: $* * * 0.001, * * 0.01, * 0.05, .0 .1 ; n s$ not significant 


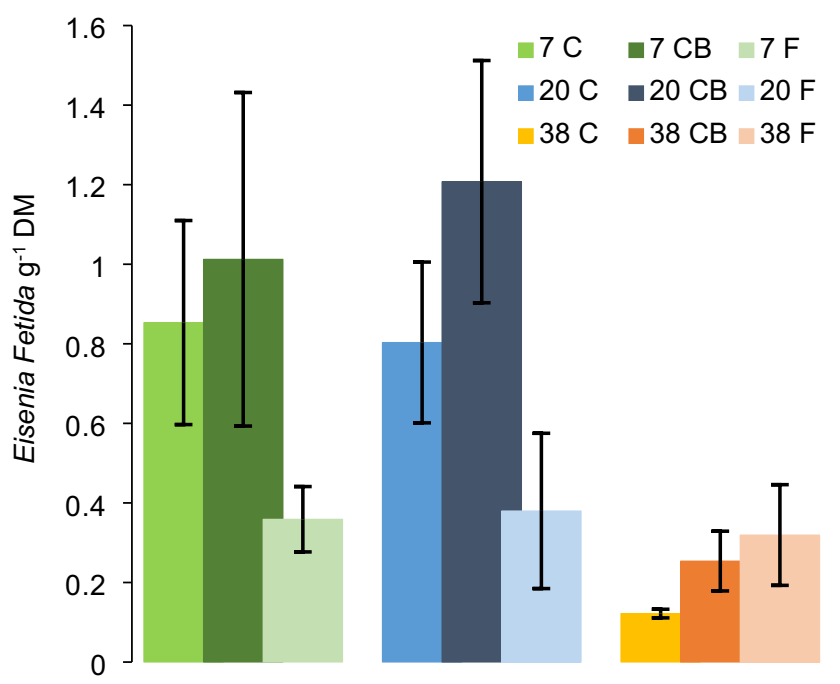

Fig. 9 Mean density of Eisenia fetida $(n=3, \pm$ SD) after vermicomposting. The treatments were previously composted/ fermented at 7,20 , and $38^{\circ} \mathrm{C}$. C, composting, CB composting with addition of biochar

treatment $(38 \mathrm{C}$ and $38 \mathrm{CB}$ ) sustained a high total $\mathrm{N}$ content and low $\mathrm{pH}$, even after vermicomposting.

Figure 9 shows the density of E. fetida in the different treatments after 77 days of vermicomposting. The worms propagated in all treatments but varied in density within the range of $0.11-1.63$ worms $\mathrm{g}^{-1} \mathrm{DM}$. Higher densities were detected in materials previously composted at $7{ }^{\circ} \mathrm{C}$ and $20^{\circ} \mathrm{C}$, whereas the lowest density is found in the $38^{\circ} \mathrm{C}$ material. In the $\mathrm{CB}$ treatments, there was a trend for higher average numbers of worms compared to the $\mathrm{C}$ treatments though not statistically significant.

The E. coli cell numbers in the samples from the vermicomposting are plotted in Fig. 10. Compared to the composting/fermentation step, E. coli counts were reduced

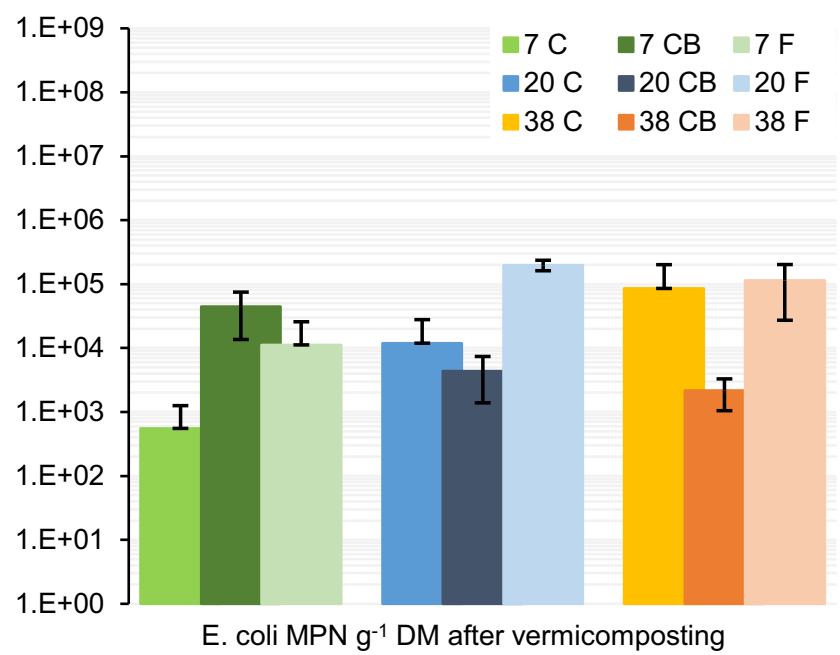

Fig. 10 Enumeration of the indicator organisms E. coli after vermicomposting. The treatments were previously composted/ fermented at 7,20 , and $38^{\circ} \mathrm{C}$. C composting, CB composting with addition of biochar. The error bars represent standard deviation values by $4-5 \log _{10}$ during the vermicomposting for the $7 \mathrm{C}$ and 7 CB treatments. However, in 20 C, 20 F, 38 C, and 38 F, higher cell numbers were detected after the vermicomposting indicating possible regrowth or contamination from the worms.

\section{Discussion}

\section{Composting at different ambient temperatures}

\section{Microbial activity in the composting process}

As evident from the temperature dynamics and the respiration rates, composting at $38^{\circ} \mathrm{C}$ supported a higher activity throughout the entire period, close to doubling the amount of respired $\mathrm{C}$ compared to composting at $20^{\circ} \mathrm{C}$. The rate of the process depends on the availability of easily degradable substrates but also on maintaining optimal conditions such as temperature and aeration moisture (Haug 1993). It is likely that the higher temperature enhanced degradation by specific biota at a higher rate resulting in more available carbon for further degradation (Zhang et al. 2011; Wang et al. 2015), whereas at $7^{\circ} \mathrm{C}$, the activity was low, and with time, the material became more compacted, the airflow was restricted, and accordingly the rate of degradation decreased. The lack of intensive degradation together with compaction, high moisture saturation, and no turning resulted in a sludge-like and water-logged material, which was not stabilized as indicated by the similar $\mathrm{VS}$ and $\mathrm{C} / \mathrm{N}$ ratio in the substrate before and after the period of composting.

The temperature profile within the composting matrix is indicative of the process rate as a measure of the released heat but at the same time subject to the dynamics between heat production and heat loss to the environment. The conductivity of the material and the amount of composting substrate influence the temperature dynamics and can heighten temperatures or result in greater heat loss and affect the development of the process. Low ambient temperatures and lack of insulation result in higher net heat loss, which in turn slows microbial degradation (Niwagaba et al. 2009; Nasri et al. 2019). On the other hand, too high ambient temperatures can inhibit microbial activity as shown by Beck-Friis et al. (2001) for composting with external heating of $55^{\circ} \mathrm{C}$.

As expected, the ambient temperature in these small-scale compost reactors without insulation had a significant effect on the composting dynamics, and an increase in the ambient temperature in the examined range between $7^{\circ} \mathrm{C}$ and $38^{\circ} \mathrm{C}$ resulted in more active and faster degradation and self-heating in the compost. 


\section{Physicochemical characteristics}

The change in the physicochemical characteristics between the initial mixtures and the materials after treatment suggests that those exposed to $38^{\circ} \mathrm{C}$ had undergone most transformation. $38 \mathrm{C}$ and $38 \mathrm{CB}$ were characterized by lowest VS and $\mathrm{C} /$ $\mathrm{N}$ ratios and highest $\mathrm{N}$ contents, indicating the material was more degraded. In the $38^{\circ} \mathrm{C}$ composts, the increase in total nitrogen was likely due to a concentration effect caused by the weight loss associated with the mineralization of organic matter (Sánchez-Monedero et al. 2001; Guo et al. 2012).

In all composting treatments, the concentration of $\mathrm{NH}_{4}-\mathrm{N}$ was reduced; however, the changes in total nitrogen indicated that most of the $\mathrm{NH}_{4}-\mathrm{N}$ was immobilized or nitrified, rather than lost through ammonia volatilization. During composting, nitrogen transformations are affected by temperature, $\mathrm{pH}$, feedstock, and aeration (Sánchez-Monedero et al. 2001; Sundh and Rönn 2002). Several factors may have contributed to the low $\mathrm{N}$ losses in this study: the relatively low temperatures of composting, suboptimal aeration levels, and returning the leachate back into the composting mix.

Measured $\mathrm{pH}$ dynamics indicated biochemical changes in the middle of the composting period for treatments at $20^{\circ} \mathrm{C}$ and at the end for those at $38^{\circ} \mathrm{C}$ and little to no change for those at $7^{\circ} \mathrm{C}$. The commonly observed trend in $\mathrm{pH}$ during composting is an initial drop due to the formation of organic acids, which is then followed by an increase and stabilization at neutral pH (Epstein 1997). In this study, the quick initial drop due to organic acid formation could have happened before Day 5, before the first measurements of $\mathrm{pH}$. An interesting phenomenon is the drop in leachate $\mathrm{pH}$ at the end of the composting at $38^{\circ} \mathrm{C}$. One possible explanation is that it is a result of intensified nitrification, as the release of $\mathrm{H}^{+}$in the nitrification process acidifies the composting mix. The study of Sánchez-Monedero et al. (2001) found a correlation between the concentration of nitrates and the $\mathrm{pH}$. Supporting that explanation are also the higher values for total nitrogen with low percent ammonium in the treatments at $38^{\circ} \mathrm{C}$.

\section{Fecal indicators}

Different ambient temperatures resulted in different postcomposting numbers of indigenous $E$. coli and enterococci with higher numbers for the treatments at $7^{\circ} \mathrm{C}$ and lower for those at $38^{\circ} \mathrm{C}$. In the treatments at $7^{\circ} \mathrm{C}$, the MPN of E. coli was considerably higher than at the other temperatures and corresponded to what has been observed in fresh feces (Germer et al. 2010; Ogunyoku et al. 2016). They were therefore considered to represent the original levels of fecal indicators, to which the other treatments were compared to.

Inactivation of pathogens during composting is related to temperature and microbial activity in the compost and is due to heat inactivation and competition with the microflora promoted by the composting process (Haug 1993). Reduction of pathogens is commonly characterized by a time-temperature relationship and is measured by $\log _{10}$ reduction or a specified abundance limit of an indicator microorganism. Common references are sanitizing temperatures of $55^{\circ} \mathrm{C}$ for a few days (Schönning and Stenström 2004) or the limit of 1000 MPN E. coli $\mathrm{g}^{-1}$ DM in the final material (Jayathilake et al. 2019). In this study, sanitizing temperatures above $55^{\circ} \mathrm{C}$ were not reached in any of the treatments. Temperatures high enough to affect the survival of pathogens were recorded only for the reactors at $38^{\circ} \mathrm{C}$. In the core of the composting mass in those treatments, the temperature exceeded $45^{\circ} \mathrm{C}$ in the first three days, and only in some, it reached temperatures above $50^{\circ} \mathrm{C}$. However, even without sanitizing temperatures, the composting process resulted in $4 \times 6 \log _{10}$ lower cell numbers of $E$. coli in the more active composts at $20^{\circ} \mathrm{C}$ and $38^{\circ} \mathrm{C}$ in comparison to the treatments at $7^{\circ} \mathrm{C}$ and $E$. coli $<1000 \mathrm{MPN} \mathrm{g}^{-1} \mathrm{DM}$ in treatment $38^{\circ} \mathrm{C}$. Enterococci have a high survival rate in composts (Vinnerås 2007) and were less affected by the temperature during the composting.

During small-scale composting of fecal sludge, sanitizing temperatures are rarely achieved (Niwagaba et al. 2009; Hill et al. 2013), but the process can still be efficient for reducing the pathogenic load (Vinnerås 2007; Germer et al. 2010). The method by which the compost is applied can introduce further $\log$ reductions due to application to soil, fertilization of crops that are not to be consumed raw, or fertilization of food crops with eatable parts that are not in contact with the soil (World Health Organization (WHO) 2006; Schönning et al. 2007).

\section{Fate of pharmaceutical compounds}

Higher concentrations of pharmaceuticals can be expected in fecal sludge from source-separated sanitation compared to conventional wastewater (Butkovskyi et al. 2015; Gros et al. 2020). Ibuprofen and caffeine were the compounds detected at highest concentrations, which reflects their high consumption in Norway. Caffeine is in some cases considered a concern to the environment due to its high concentrations (Deblonde et al. 2011; Verlicchi and Zambello 2015). The initial concentrations of carbamazepine were also relatively high compared to what has been reported for wastewater and sludge (Martín et al. 2015; Verlicchi and Zambello 2015); nevertheless, Gros et al. (2020) reported higher concentrations in fecal sludge solids. Carbamazepine is a persistent, neutral compound that partitions to solids (Butkovskyi et al. 2015; Min et al. 2018; de Wilt et al. 2018), which can explain a possible accumulation over time in fecal solids.

The results of our study indicate a positive correlation between temperature and the removal/degradation of caffeine, atorvastatin, losartan, diclofenac, and warfarin. The concentrations in the treatment products were lower at a higher 
temperature. However, as shown, the composting was also more active at higher temperatures; thus, it is not possible to discuss the effects of temperature and composting activity separately. Both thermal decomposition and microbial transformation are possible mechanisms for the observed reduction. Most of those compounds have been shown to be biodegradable. Caffeine has been identified as an easily degradable compound (Deblonde et al. 2011; de Wilt et al. 2018). In comparison between mesophilic and thermophilic anaerobic digestion, Gros et al. (2020) demonstrated more efficient removal of atorvastatin in a thermophilic treatment.

\section{Effect of the biochar}

Addition of biochar had no clear effect on the measured endpoints in any of the temperature treatments. Addition of $\sim$ vol. $5 \%$ biochar did not result in changes in the temperature profile or the dynamics of $\mathrm{CO}_{2}$ evolution. At $7^{\circ} \mathrm{C}$ and $20^{\circ} \mathrm{C}$, though, the $\mathrm{CB}$ treatments had lower cumulative $\mathrm{CO}_{2}$ emissions and higher $\mathrm{pH}$ in comparison to the $\mathrm{C}$ treatments. There was no significant difference in the $E$. coli and enterococci between the compost with and without biochar. However, the pharmaceutical compounds carbamazepine and diclofenac had lower concentrations in the $\mathrm{CB}$ compared to the $\mathrm{C}$ treatment products. Carbamazepine is resistant to degradation and is mostly removed by sorption (Min et al. 2018; de Wilt et al. 2018), and biochar has been shown previously to be an efficient sorbent (Dalahmeh et al. 2018). Both carbamazepine and diclofenac are considered as high risk for the environment (Butkovskyi et al. 2016), suggesting that biochar addition in fecal matter subjected to composting can be used to mitigate the environmental effect of these compounds.

In a study on poultry litter composting, Steiner et al. (2010) found that $5 \%$ biochar had little to no effect, whereas addition of $20 \%$ biochar resulted in faster decomposition and lower nitrogen losses. Therefore, it would be interesting to investigate additions of biochar larger than 5\%, particularly for its role for retaining nutrients and pharmaceuticals. However, larger amounts of biochar can result in alkaline $\mathrm{pH}$, especially when composting organics with high initial $\mathrm{pH}$, and thus inhibit composting through negative effects on the microorganisms (Khan et al. 2020). Different feedstocks, process conditions and amounts of biochar will give different results (Wu et al. 2017; Khan et al. 2020).

\section{Lactic acid fermentation}

Sufficient production of lactic acid and sustained acidity are key factors for the LAF process and elimination of pathogens (Odey et al. 2018b). In this study, lactic acid was not measured, and it was not possible to monitor the $\mathrm{pH}$ as little or no leachate was produced. The few $\mathrm{pH}$ measurements in leachate during the first days indicated acidification, but the $\mathrm{pH}$ measured in samples from Day 71 revealed that acidity was not maintained. It is therefore difficult to judge how successful was the LAF process.

\section{LAF at different ambient temperatures}

Comparison of physicochemical properties did not show significant effect of temperature on the LAF process. This was also indirectly confirmed by the results of the vermicomposting. Both the presence of fecal indicators and the density of worms after the vermicomposting did not differ significantly between LAF treatments conducted at different temperatures. There are no studies so far investigating LAF of fecal matter under different temperatures, but the existing literature suggests that higher temperatures $\left(20-55^{\circ} \mathrm{C}\right)$ enhance the fermentation (Tang et al. 2016; Zhou et al. 2016).

\section{Physicochemical characteristics}

LAF products are typically characterized by low $\mathrm{pH}$, high content of organic acids, and low decomposition (Andreev et al. 2017). The higher $\mathrm{C} / \mathrm{N}$ ratio and high content of $\mathrm{NH}_{4^{-}}$ $\mathrm{N}$ in $7 \mathrm{~F}, 20 \mathrm{~F}$, and $38 \mathrm{~F}$ corroborate this principal difference to the composting process. Studies have shown that LAF retains nutrients and organic carbon (Andreev et al. 2018). In the present study, even though post-treatment $\mathrm{NH}_{4}-\mathrm{N}$ was high, total nitrogen was similar to the composting treatments; therefore, this experiment does not confirm higher retention of nitrogen in LAF compared to composting. A probable explanation is a high retention of $\mathrm{N}$ in the composting treatments because the leachate was returned to the mix, as well as lower temperatures and therefore a lower activity in the compost as shown by the respiration data.

\section{Fecal indicators}

The MPNs of E. coli and enterococci suggest that the material was not properly sanitized (E. coli $>1000$ MPN g ${ }^{-1} \mathrm{DM}$ ). Interestingly though, in $7 \mathrm{~F}$, the $E$. coli numbers were approximately $5 \log _{10}$ lower than in $7 \mathrm{C}$ and $7 \mathrm{CB}$. LAF has been shown to efficiently reduce fecal indicator bacteria (Anderson et al. 2015; Andreev et al. 2017; Odey et al. 2018b). However, it has not been extensively researched whether LAF has a specific effect on fecal pathogens, nor whether the reduction in the indicator organisms is related to a reduction in other relevant pathogens like Salmonella, Ascaris sp., and viruses.

\section{Fate of pharmaceutical compounds}

To the best of our knowledge, there are no studies that have investigated LAF of fecal matter or wastewater in regard to its effect on pharmaceutical compounds. LAF is mostly utilized for food preservation and as such can be expected to have 
minimal effect on degradation of organic compounds. Our study confirmed degradation by LAF for most of the detected compounds, but post-treatment concentration of caffeine, ibuprofen, acetaminophen, metoprolol, and warfarin clearly suggested more efficient removal by composting than LAF. Caffeine and acetaminophen are easily degradable compounds (de Graaff et al. 2011; Deblonde et al. 2011; de Wilt et al. 2018). Ibuprofen has been shown to have high biodegradability in aerobic treatments and low in anaerobic treatments (de Graaff et al. 2011; Butkovskyi et al. 2016; Min et al. 2018; de Wilt et al. 2018). Metoprolol has been shown to be recalcitrant under anaerobic conditions and with better removal in aerobic compared to anaerobic conditions (de Graaff et al. 2011; de Wilt et al. 2018). The concentrations of carbamazepine varied between replicates but on average showed the same trend. In contrast, atorvastatin, losartan, and diclofenac were detected in lower concentrations in the fermentation products compared to the composting products. Those are anionic compounds with better sorption at low $\mathrm{pH}$ (atorvastatin $\mathrm{pKa}=4.46$, losartan $\mathrm{pKa}=5.5$, diclofenac $\mathrm{pKa}=$ 4.15 (PubChem 2020), Online Resource Table S1). Thus, removal of pharmaceutical compounds in LAF seems to be mostly due to sorption, whereas the main mechanism in composting seems to be aerobic biodegradation.

\section{Vermicomposting}

Worms from the species E. fetida were introduced to the treatment mixtures after the first composting/fermentation step and multiplied in numbers in all treatments over a period of 77 days. The earthworms were successfully established in the $7^{\circ} \mathrm{C}$ and $20^{\circ} \mathrm{C}$ treatments but thrived less in the $38 \mathrm{C}$ and all $\mathrm{LAF}$ treatments. Possible explanations could be the lower $\mathrm{pH}$ after $38^{\circ} \mathrm{C}$, more stabilized organic material that has a lower food value for the worms, and the high $\mathrm{NH}_{4}-\mathrm{N}$ in the fermentation treatments (Edwards et al. 2010). It should be noted that the enumeration method did not differentiate between different development stages of E. fetida and therefore represents only a snapshot of the population in each treatment on the day of the collection. However, the comparison is comprehensive and supported by changes in physiochemical characteristics and E. coli MPN.

Vermicomposting further stabilized the material from all treatments, as evidenced by further reduction in VS and $\mathrm{NH}_{4}$ content. In that respect, the process significantly altered the 7 $\mathrm{C}$ and $7 \mathrm{CB}$ treatments. The treatments at $7^{\circ} \mathrm{C}$ underwent less active composting, and the substrate was sludge-like after the first composting step. Earthworm activity during vermicomposting resulted in improved mixing and aeration and facilitated further decomposition and stabilization.

The composting treatments $7 \mathrm{C}, 7 \mathrm{CB}$, and $20 \mathrm{C}, 20 \mathrm{CB}$, which had the highest density of E. fetida, had the lowest numbers of $E$. coli, whereas the treatments with lower densities showed higher $E$. coli counts in comparison to after the composting. This negative relationship between worm density and $E$. coli counts suggests that vermicomposting as post-treatment of fecal matter can reduce the load of fecal pathogens, particularly after ineffective composting. An increase in the fecal indicators after vermicomposting could be due to regrowth of bacteria or contamination from the worms (Lalander et al. 2013b). Vermicomposting has been shown to reduce pathogens from dry sanitation systems (Hill and Baldwin 2012; Yadav et al. 2012; Lalander et al. 2013b). However, the studies so far have focused on indicator organisms, and there are knowledge gaps with regard to effects on variety of pathogens and correlations to vermicomposting parameters such as feedstock, worm density, and temperature.

\section{Practical significance}

This study showed that ambient temperature has a significant effect on compost quality and removal of pathogens during on-site small-scale composting of fecal matter. In colder environments, this should be considered, as low temperature inhibits biological processes. Different options can be considered to ensure higher temperatures, such as heat preserving insulation (Vinnerås et al. 2003), addition of easily degradable substrate to trigger fast decomposition, and self-heating (Germer et al. 2010) or external heating. Insulation is an easy optimization, but it depends on a well-maintained composting process and self-heating of the substrate. Easily degradable substrates can come from domestic food waste but are subject to availability and of variable composition. External heating can be energy demanding, and in areas with high solar irradiance, passive solar heating could be a sustainable way to achieve higher temperatures (Redlinger et al. 2001; Kelova 2015).

Maintaining active composting can be limited by the local context due to environmental, economic, or cultural constraints. Composting activity is sensitive to moisture content, aeration, and bulking materials, and the control of these variables requires some level of expertise. Therefore, depending on the context, small-scale composting might not be the most suitable solution for on-site management of fecal sludge. By contrast, LAF does not require maintenance, can be operated in a shorter time period, and results in a reduction of E. coli comparable to composting at $20^{\circ} \mathrm{C}$. It has therefore been considered a suitable option in an emergency context (Anderson et al. 2015). However, its product requires further treatment before application to agriculture. Vermicomposting is another option. In our study, the activity of the earthworms transformed and stabilized the material where composting was ineffective. Hill and Baldwin (2012) reported that 
vermicomposting toilets can produce more stable material with fewer fecal indicators in comparison to inefficiently managed composting toilets, the majority of which were operated at low ambient temperatures.

Recirculating the nutrients and organic matter from fecal matter back to the soil for crop and food production requires better understanding of the fate of pharmaceutical compounds that are released to the environment. We found that higher microbial activity and temperature in the compost resulted in more efficient removal of most of the investigated compounds. The main mechanism of removal of pharmaceuticals, therefore, is probably biodegradation under aerobic conditions. By contrast, LAF had minimal effect on the concentrations of most of the investigated pharmaceuticals, except for atorvastatin, losartan, and diclofenac, and sorption is assumed as a removal mechanism. Slowly degrading compounds such as carbamazepine, diclofenac, metoprolol, and losartan can still pose a risk to the environment; however, that can be mitigated by further treatment. Overall, combinations of LAF and composting for removal of pharmaceuticals would be an interesting enquiry due to the different effects these treatments have in combination, which might result in overall larger reduction.

\section{Conclusions}

Our investigation compared composting of fecal matter with lactic acid fermentation under three different temperatures. Ambient temperature had a significant effect on the composting process and the quality of the resulting material. At $7^{\circ} \mathrm{C}$, composting was less active, which resulted in limited transformation and material with high numbers of fecal indicators and pharmaceuticals. At $20^{\circ} \mathrm{C}$, composting was more active, and the outcome was a more stabilized material with lower numbers of fecal indicators and more efficient reduction in concentrations of a variety of pharmaceutical compounds. At $38^{\circ} \mathrm{C}$, the composting process resulted in the most stabilized and sanitized material. The addition of $\sim$ vol. $5 \%$ biochar to the composting did not yield significant differences in the measured parameters. While the active composting at $20^{\circ} \mathrm{C}$ and $38^{\circ} \mathrm{C}$ yielded more stabilized material with less $E$. coli and pharmaceuticals, lactic acid fermentation was comparatively successful in reducing the number of $E$. coli at $7^{\circ} \mathrm{C}$. The lactic acid fermentation, however, was not assessed with respect to lactic acid production and retained acidity, which limited the comparison with composting. The secondary treatment with vermicomposting resulted in further maturation and stabilization of the material in all treatments, and it was particularly beneficial in reducing $E$. coli numbers and transforming the substrates for the treatments that were previously composted at lower temperatures, i.e., $7^{\circ} \mathrm{C}$ and $20^{\circ} \mathrm{C}$.
The results of our investigation highlight the limitations of composting at low temperature and how other treatments as lactic acid fermentation or vermicomposting can be a valuable alternative, particularly when composting is not successful. Therefore, depending on the local conditions, possibilities, and desired qualities of the end product, different alternatives for resource recovery can be considered. Sustainable utilization of the resources from on-site sanitation treatment of human excreta will also depend on expanding the knowledge on the nutrient values in these treatment products and how they can be best utilized in the local agroecosystems.

Supplementary Information The online version contains supplementary material available at https://doi.org/10.1007/s11356-021-12911-z.

Acknowledgements The authors would like to express their profound appreciation to Tore Krogstad and the soil science's laboratory at NMBU for their invaluable expertise and help with analysis of physicochemical characteristics. The NMBU Department of Food Safety and Infection Biology (MatInf) allowed access to their analytical laboratories where the pharmaceutical analysis was conducted. The authors would like to thank Melesse Mogens and Arve Heistad for their advice and help with enumeration of fecal indicators. Thanks also to Lindum $\mathrm{A} / \mathrm{S}$ and specifically Alene Tesfamichel for supplying the E. fetida worms and to Mattias Gustafsson and Stockholm Vatten och Avfall for supplying the biochar.

Author contribution Conceptualization: MK, AA, SE, PD, RK, and PJ. Methodology: MK, AA, SE, and PD. Formal analyses and investigation: MK and AA. Writing - original draft preparation: MK and AA. Writing review \& editing: AA, SE, PD, RK, and PJ. Funding acquisition: SE and PJ. Supervision: SE, RK, and PJ. All authors read and approved the final manuscript.

Funding Open access funding provided by Norwegian University of Life Sciences. This study was funded by the Norwegian University of Life Sciences (NMBU), Faculty of Environmental Sciences and Natural Resource Management.

Data and materials availability The datasets used and analyzed during the current study are stored in the institutional repository at the Norwegian University of Life Sciences (NMBU), Faculty of Environmental Sciences and Natural Resource Management and so are not publicly available. Data are however available from the corresponding author on reasonable request.

\section{Declarations}

Ethics approval and consent to participate Not applicable

Consent for publication Not applicable

Competing interests The authors declare no competing interests.

Open Access This article is licensed under a Creative Commons Attribution 4.0 International License, which permits use, sharing, adaptation, distribution and reproduction in any medium or format, as long as you give appropriate credit to the original author(s) and the source, provide a link to the Creative Commons licence, and indicate if 
changes were made. The images or other third party material in this article are included in the article's Creative Commons licence, unless indicated otherwise in a credit line to the material. If material is not included in the article's Creative Commons licence and your intended use is not permitted by statutory regulation or exceeds the permitted use, you will need to obtain permission directly from the copyright holder. To view a copy of this licence, visit http://creativecommons.org/licenses/by/4.0/.

\section{References}

Ali AM, Nesse AS, Eich-Greatorex S, Sogn TA, Aanrud SG, Aasen Bunæs JA, Lyche JL, Kallenborn R (2019) Organic contaminants of emerging concern in Norwegian digestates from biogas production. Environ Sci Process Impacts 21:1498-1508. https://doi.org/10. 1039/c9em00175a

American Public Health Association \& Water Environment Federation (APHA) (2005) Standard methods for the examination of water and wastewater, 21st edn. American Public Health Association, Washington, DC, USA

Anderson C, Malambo DH, Perez MEG, Nobela H, de Pooter L, Spit J, Hooijmans C, de Vossenberg J, Greya W, Thole B, van Lier J, Brdjanovic D (2015) Lactic acid fermentation, urea and lime addition: promising faecal sludge sanitizing methods for emergency sanitation. Int J Environ Res Public Health 12:13871-13885. https:// doi.org/10.3390/ijerph121113871

Andreev N, Ronteltap M, Lens PNL, Boincean B, Bulat L, Zubcov E (2016) Lacto-fermented mix of faeces and bio-waste supplemented by biochar improves the growth and yield of corn (Zea mays L.). Agric Ecosyst Environ 232:263-272. https://doi.org/10.1016/j.agee. 2016.08.012

Andreev N, Ronteltap M, Boincean B, Lens PNL (2017) Treatment of source-separated human feces via lactic acid fermentation combined with thermophilic composting. Compost Sci Util 25:220-230. https://doi.org/10.1080/1065657X.2016.1277809

Andreev N, Ronteltap M, Boincean B, Lens PNL (2018) Lactic acid fermentation of human excreta for agricultural application. J Environ Manage 206:890-900. https://doi.org/10.1016/j.jenvman. 2017.11.072

Beck-Friis B, Smårs S, Jönsson H, Kirchmann H (2001) Gaseous emissions of carbon dioxide, ammonia and nitrous oxide from organic household waste in a compost reactor under different temperature regimes. J Agric Eng Res 78:423-430. https://doi.org/10.1006/jaer. 2000.0662

Bremner JM, Mulvaney CS (1982) Nitrogen-Total. In: Page AL, Miller RH, Keeney DR (eds) Methods of soil analysis. Part 2. Chemical and microbiological properties. American Society of Agronomy, Madison, pp 595-624

Butkovskyi A, Hernandez Leal L, Rijnaarts HHM, Zeeman G (2015) Fate of pharmaceuticals in full-scale source separated sanitation system. Water Res 85:384-392. https://doi.org/10.1016/j.watres.2015.08. 045

Butkovskyi A, Ni G, Hernandez Leal L, Rijnaarts HHM, Zeeman G (2016) Mitigation of micropollutants for black water application in agriculture via composting of anaerobic sludge. J Hazard Mater 303: 41-47. https://doi.org/10.1016/j.jhazmat.2015.10.016

Chen W, Luo S, Du S et al (2020) Strategy to strengthen rural domestic waste composting at low temperature: choice of ventilation condition. Waste and Biomass Valorization. 11:6649-6665. https://doi. org/10.1007/s12649-020-00943-4

Dalahmeh S, Ahrens L, Gros M, Wiberg K, Pell M (2018) Potential of biochar filters for onsite sewage treatment: adsorption and biological degradation of pharmaceuticals in laboratory filters with active, inactive and no biofilm. Sci Total Environ 612:192-201. https:// doi.org/10.1016/j.scitotenv.2017.08.178

De Gisi S, Petta L, Wendland C (2014) History and technology of Terra Preta sanitation. Sustainability 6:1328-1345. https://doi.org/10. 3390/su6031328

de Graaff MS, Vieno NM, Kujawa-Roeleveld K, Zeeman G, Temmink H, Buisman CJN (2011) Fate of hormones and pharmaceuticals during combined anaerobic treatment and nitrogen removal by partial nitritation-anammox in vacuum collected black water. Water Res 45:375-383. https://doi.org/10.1016/j.watres.2010.08.023

de Oliveira M, Farias Frihling BE, Velasques J et al (2020) Pharmaceuticals residues and xenobiotics contaminants: occurrence, analytical techniques and sustainable alternatives for wastewater treatment. Sci Total Environ 705:135568. https://doi.org/10.1016/j. scitotenv.2019.135568

de Wilt A, He Y, Sutton N, Langenhoff A, Rijnaarts H (2018) Sorption and biodegradation of six pharmaceutically active compounds under four different redox conditions. Chemosphere 193:811-819. https:// doi.org/10.1016/j.chemosphere.2017.11.084

Deblonde T, Cossu-Leguille C, Hartemann P (2011) Emerging pollutants in wastewater: a review of the literature. Int J Hyg Environ Health 214:442-448. https://doi.org/10.1016/j.ijheh.2011.08.002

Edwards CA, Arancon NQ, Sherman RL (2010) Vermiculture technology: earthworms, organic wastes, and environmental management. CRC Press

Eklind Y, Sundberg C, Smårs S, Steger K, Sundh I, Kirchmann H, Jönsson H (2007) Carbon turnover and ammonia emissions during composting of biowaste at different temperatures. J Environ Qual 36:1512-1520. https://doi.org/10.2134/jeq2006.0253

Epstein E (1997) The science of composting. Pa: Technomic., Lancaster Germer J, Boh MY, Schoeffler M, Amoah P (2010) Temperature and deactivation of microbial faecal indicators during small scale cocomposting of faecal matter. Waste Manag. 30:185-191. https:// doi.org/10.1016/j.wasman.2009.09.030

Gros M, Ahrens L, Levén L, Koch A, Dalahmeh S, Ljung E, Lundin G, Jönsson H, Eveborn D, Wiberg K (2020) Pharmaceuticals in source separated sanitation systems: fecal sludge and blackwater treatment. Sci Total Environ 703:. https://doi.org/10.1016/j.scitotenv.2019. 135530

Guo R, Li G, Jiang T, Schuchardt F, Chen T, Zhao Y, Shen Y (2012) Effect of aeration rate, $\mathrm{C} / \mathrm{N}$ ratio and moisture content on the stability and maturity of compost. Bioresour Technol 112:171-178. https://doi.org/10.1016/j.biortech.2012.02.099

Hashemi S, Boudaghpour S, Han M (2019) Evaluation of different natural additives effects on the composting process of source separated feces in resource-oriented sanitation systems. Ecotoxicol Environ Saf 185:109667. https://doi.org/10.1016/j.ecoenv.2019.109667

Haug R T (1993) The practical handbook of compost engineering. Fla: Lewis Publishers, Boca Raton

Hester RE, Harrison RM (eds) (2016) Pharmaceuticals in the environment. The Royal Society of Chemistry

Hijikata N, Yamauchi N, Ishiguro M, Ushijima K, Funamizu N (2015) Suitability of biochar as a matrix for improving the performance of composting toilets. Waste Manag Res 33:313-321

Hill GB, Baldwin SA (2012) Vermicomposting toilets, an alternative to latrine style microbial composting toilets, prove far superior in mass reduction, pathogen destruction, compost quality, and operational cost. Waste Manag. 32:1811-1820. https://doi.org/10.1016/j. wasman.2012.04.023

Hill GB, Baldwin SA, Vinnerås B (2013) Composting toilets a misnomer: excessive ammonia from urine inhibits microbial activity yet is insufficient in sanitizing the end-product. J Environ Manage 119:29 35. https://doi.org/10.1016/j.jenvman.2012.12.046

Jayathilake N, Drechsel P, Keraita B, et al (2019) Guidelines and regulations for fecal sludge management from on-site sanitation facilities. 57p. https://doi.org/10.22004/ag.econ.296740 
Jewell KS, Wick A, Ternes TA (2014) Comparisons between abiotic nitration and biotransformation reactions of phenolic micropollutants in activated sludge. WATER Res 48:478-489. https://doi.org/10.1016/j.watres.2013.10.010

Kelova ME (2015) Assessment of a prototype of composting toilet. Field scale study assessing the design, performance and potential of the prototype. (Unpublished master's thesis) Norwegian University of Life Sciences (NMBU)

Khan MB, Cui X, Jilani G, Tang L, Lu M, Cao X, Sahito ZA, Hamid Y, Hussain B, Yang X, He Z (2020) New insight into the impact of biochar during vermi-stabilization of divergent biowastes: literature synthesis and research pursuits. Chemosphere 238:124679. https:// doi.org/10.1016/j.chemosphere.2019.124679

Lalander C, Diener S, Magri ME, Zurbrügg C, Lindström A, Vinnerås B (2013a) Faecal sludge management with the larvae of the black soldier fly (Hermetia illucens) - from a hygiene aspect. Sci Total Environ 458:312-318. https://doi.org/10.1016/j.scitotenv.2013.04. 033

Lalander CH, Hill GB, Vinnerås B (2013b) Hygienic quality of faeces treated in urine diverting vermicomposting toilets. Waste Manag. 33:2204-2210. https://doi.org/10.1016/j.wasman.2013.07.007

Leclercq M, Mathieu O, Gomez E, Casellas C, Fenet H, Hillaire-Buys D (2009) Presence and fate of carbamazepine, oxcarbazepine, and seven of their metabolites at wastewater treatment plants. Arch Environ Contam Toxicol 56:408-415. https://doi.org/10.1007/s00244-0089202-x

Lim SL, Lee LH, Wu TY (2016) Sustainability of using composting and vermicomposting technologies for organic solid waste biotransformation: recent overview, greenhouse gases emissions and economic analysis. J. Clean. Prod. 111:262-278

Martín J, Santos JL, Aparicio I, Alonso E (2015) Pharmaceutically active compounds in sludge stabilization treatments: anaerobic and aerobic digestion, wastewater stabilization ponds and composting. Sci Total Environ 503-504:97-104. https://doi.org/10.1016/j.scitotenv.2014. 05.089

McConville JR, Kvarnström E, Nordin AC, et al (2020) Structured approach for comparison of treatment options for nutrient-recovery from fecal sludge. Front Environ Sci 8:. https://doi.org/10.3389/ fenvs.2020.00036

McKinley JW, Parzen RE, Mercado Guzman A (2012) Impact of climate and bulking materials on characteristics of compost from ecological toilets. J Water, Sanit Hygeine Dev 2:79-86. https://doi.org/10. 2166/washdev.2012.059

Min X, Li W, Wei Z, Spinney R, Dionysiou DD, Seo Y, Tang CJ, Li Q, Xiao R (2018) Sorption and biodegradation of pharmaceuticals in aerobic activated sludge system: a combined experimental and theoretical mechanistic study. Chem Eng J 342:211-219. https://doi. org/10.1016/j.cej.2018.01.012

Nasri B, Brun F, Fouché O (2019) Evaluation of the quality and quantity of compost and leachate from household waterless toilets in France. Environ Sci Pollut Res 26:2062-2078. https://doi.org/10.1007/ s11356-017-0604-z

Nelson DW, Sommers LE (1982) Total carbon, organic carbon and organic matter. In: A.L. Page RHM and DRK (ed) Methods of soil analysis. Part 2 Chemical and microbiological properties. American Society of Agronomy, Madison, Wisconsin, pp 539-579

Niwagaba C, Nalubega M, Vinnerås B, Sundberg C, Jönsson H (2009) Bench-scale composting of source-separated human faeces for sanitation. Waste Manag 29:585-589. https://doi.org/10.1016/j. wasman.2008.06.022

Odey EA, Li Z, Zhou X, Yan Y (2018a) Optimization of lactic acid fermentation for pathogen inactivation in fecal sludge. Ecotoxicol Environ Saf 157:249-254. https://doi.org/10.1016/j.ecoenv.2018. 03.075

Odey EA, Li Z, Zhou X, Yan Y (2018b) Locally produced lactic acid bacteria for pathogen inactivation and odor control in fecal sludge. $\mathrm{J}$
Clean Prod 184:798-805. https://doi.org/10.1016/j.jclepro.2018.02. 276

Ogunyoku TA, Habebo F, Nelson KL (2016) In-toilet disinfection of fresh fecal sludge with ammonia naturally present in excreta. $\mathrm{J}$ Water, Sanit Hygeine Dev 6:104-114. https://doi.org/10.2166/ washdev.2015.233

Orner KD, Mihelcic JR (2018) A review of sanitation technologies to achieve multiple sustainable development goals that promote resource recovery. Environ Sci Res Technol 4:16-32. https://doi.org/ $10.1039 / \mathrm{c} 7 \mathrm{ew} 00195 \mathrm{a}$

PubChem (2020) National Center for Biotechnology Information. PubChem Database. https://pubchem.ncbi.nlm.nih.gov. Accessed 13 Jun 2020

Redlinger T, Graham J, Corella-Barud V, Avitia R (2001) Survival of fecal coliforms in dry-composting toilets. Appl Environ Microbiol. 67:4036-4040. https://doi.org/10.1128/AEM.67.9.4036-4040.2001

Sánchez-Monedero MA, Roig A, Paredes C, Bernal MP (2001) Nitrogen transformation during organic waste composting by the Rutgers system and its effects on $\mathrm{pH}, \mathrm{EC}$ and maturity of the composting mixtures. Bioresour Technol 78:301-308. https://doi.org/10.1016/ S0960-8524(01)00031-1

Schönning C, Stenström TA (2004) Guidelines on the safe use of urine and faeces in ecological sanitation systems. EcoSanRes Rep

Schönning C, Westrell TA, Stenström TA et al (2007) Microbial risk assessment of local handling and use of human faeces. J Water Health 5:117-128

Steiner C, Das KC, Melear N, Lakly D (2010) Reducing nitrogen loss during poultry litter composting using biochar. J Environ Qual 39: 1236-1242. https://doi.org/10.2134/jeq2009.0337

Stockholm Biochar Project (2017) https://biochar.international/launchstockholm-biochar-project-pyrolysis-pilot-plant-march-2017/

Strande L, Brdjanovic D (2014) Faecal sludge management systems. IWA publishing

Sundberg C, Smårs S, Jönsson H (2004) Low pH as an inhibiting factor in the transition from mesophilic to thermophilic phase in composting. Bioresour Technol. 95:145-150. https://doi.org/10.1016/j.biortech. 2004.01.016

Sundh I, Rönn S (2002) Microbial succession during composting of source-separated urban organic household waste under different initial temperature conditions. In: Microbiology of composting. Springer, Berlin Heidelberg, pp 53-64

Tang J, Wang X, Hu Y, Zhang Y, Li Y (2016) Lactic acid fermentation from food waste with indigenous microbiota: effects of $\mathrm{pH}$, temperature and high OLR. Waste Manag 52:278-285. https://doi.org/10. 1016/j.wasman.2016.03.034

Tilley E, Lüthi C, Morel A, et al (2014) Compendium of sanitation systems and technologies. Swiss Federal Institute of Aquatic Science and Technology (EAWAG)

Verlicchi P, Zambello E (2015) Pharmaceuticals and personal care products in untreated and treated sewage sludge: occurrence and environmental risk in the case of application on soil - a critical review. Sci Total Environ 538:750-767. https://doi.org/10.1016/j.scitotenv. 2015.08.108

Vinnerås B (2007) Comparison of composting, storage and urea treatment for sanitising of faecal matter and manure. Bioresour Technol. 98:3317-3321. https://doi.org/10.1016/j.biortech.2006.07.011

Vinnerås B, Björklund A, Jönsson H (2003) Thermal composting of faecal matter as treatment and possible disinfection method - laboratory-scale and pilot-scale studies. Bioresour Technol. 88:47-54. https://doi.org/10.1016/S0960-8524(02)00268-7

Wang X, Cui H, Shi J, Zhao X, Zhao Y, Wei Z (2015) Relationship between bacterial diversity and environmental parameters during composting of different raw materials. Bioresour Technol 198: 395-402. https://doi.org/10.1016/j.biortech.2015.09.041 
WHO and UNICEF (2017) Progress on drinking water, sanitation and hygiene: 2017 update and SDG baseline. World Heal Organ 66:84 89. https://doi.org/10.1016/j.pnpbp.2017.06.016

World Health Organization (WHO) (2006) Guidelines for the safe use of wastewater, excreta and greywater

Wu H, Lai C, Zeng G, Liang J, Chen J, Xu J, Dai J, Li X, Liu J, Chen M, $\mathrm{Lu} \mathrm{L}, \mathrm{Hu} \mathrm{L}$, Wan J (2017) The interactions of composting and biochar and their implications for soil amendment and pollution remediation: a review. Crit Rev Biotechnol 37:754-764. https:// doi.org/10.1080/07388551.2016.1232696

Yadav KD, Tare V, Ahammed MM (2011) Vermicomposting of sourceseparated human faeces by Eisenia fetida: effect of stocking density on feed consumption rate, growth characteristics and vermicompost production. Waste Manag 31:1162-1168. https://doi.org/10.1016/j. wasman.2011.02.008
Yadav KD, Tare V, Ahammed MM (2012) Integrated compostingvermicomposting process for stabilization of human faecal slurry. Ecol Eng 47:24-29. https://doi.org/10.1016/j.ecoleng.2012.06.039

Zhang J, Zeng G, Chen Y, Yu M, Yu Z, Li H, Yu Y, Huang H (2011) Effects of physico-chemical parameters on the bacterial and fungal communities during agricultural waste composting. Bioresour Technol 102:2950-2956. https://doi.org/10.1016/j.biortech.2010. 11.089

Zhou Y, Drouin P, Lafrenière C (2016) Effect of temperature $\left(5-25^{\circ} \mathrm{C}\right)$ on epiphytic lactic acid bacteria populations and fermentation of wholeplant corn silage. J Appl Microbiol 121:657-671. https://doi.org/10. 1111/jam. 13198

Publisher's note Springer Nature remains neutral with regard to jurisdictional claims in published maps and institutional affiliations. 